\title{
Grundtvig og fundamentalismen
}

\author{
Af Kim Arne Pedersen
}

Grundtvigs forhold til Bibelen undersøges med henblik på spørgsmålet om, hvorvidt dette efter 1810 kan betegnes som fundamentalistisk, og om der i så fald er tale om selvopgør eller blivende fundamentalistisk verdensanskuelse hos Grundtvig efter 1824/1825. Der arbejdes med en teologisk/teologihistorisk og en profanhistorisk fundamentalisme-definition. Profanhistorisk bestemmes fundamentalismen som karakteriseret af en reaktion på samfundets modernisering og sekularisering i modernitetens anden fase efter 1850 , og med basis i Grundtvigs placering i tid, hans afvisning af verbalinspirationen, hans modernitetsbevidsthed og hans dermed forbundne accept af videnskabelig frihed afvises en bestemmelse af Grundtvig som fundamentalist.

\section{Indledning}

Gjorde Grundtvig op med sin hidtidige bibelfundamentalisme i 1824$1825 ?^{1}$ Selve begrebet "selvopgør" har fået vægt i fortolkningshistorien i kraft af Kaj Thanings bastante tese om, at Grundtvig i 18311832 skriver sig til klarhed over forholdet mellem menneskeliv og kristendom, idet denne klarhed medfører hans opgør med den bods- og pilgrimskristendom, han indtil da har været præget af $^{2}$. Men Grundtvig har dybest set også selv opfattet sit liv som bestemt af en række gennembrud, om end alene 1810 for ham har status som et grundlæggende, omkalfatrende selvopgør, og derfor giver det god mening at arbejde med begrebet $(G E, 60)$. Men er det rigtigt, at Grundtvig i 1810 bliver fundamentalist, men bryder med fundamentalismen i 1824 ? I de senere år har man kunnet møde den påstand igen og igen, at Grundtvig var fundamentalist, en påstand, der her skal undersøges på baggrund af en historisk oversigt over de skiftende syn på Grundtvig og Bibelen samt over fundamentalismen og fundamentalisme-begrebet.

\section{Indledende bemaerkninger om Grundtvig og fundamentalisme}

Selve begrebet fundamentalisme er forholdsvis nyt - fra begyndelsen af det 20. århundrede. I de sidste 5-10 år har begrebet spillet en stadig større rolle i forbindelse med eksempelvis højrekristnes politiske indflydelse i USA, islamiske bevægelser, jødiske ortodokse grupper og hindunationalister i Indien ${ }^{3}$. Men begrebet bruges også i daglig tale om personer, der forstokket fremfører det samme synspunkt uden at 
argumentere for det og uden at lade sig rokke af argumenter - "det er ren fundamentalisme" siger man! ${ }^{4}$

Siden 1998 har dr. phil. Ole Vind knyttet begrebet sammen med Grundtvig. Ole Vind fortolker Grundtvig som fundamentalist, fordi Grundtvig for ham gennemfører en "læsning, der betragter Genesis som udtryk for en bogstavelig læsning af de bibelske tekster som bevidst modsvar til moderne forsøg på historisk-kritisk læsning eller for eksempel evolutionslærens undergravning af den bogstavelige betydning" (Vind 1998, 208). Videre anklager Vind med udgangspunkt i Grundtvigs tolkning af Babelsmyten Grundtvig for gennem sit "fundamentalistiske bibelsyn" at gøre "den etniske skabelsesmyte lige så central som" (ibid., 271) skabelsesmyten, hvorfor der ifølge Vind hos Grundtvig "ikke er langt fra en bibelsk nationalisme til en bibelsk racisme" (ibid., 468). Vind benytter her et "idehistorisk" fundamentalisme-begreb - tilsyneladende Vinds egen konstruktion. I et interview fra de senere år medgiver Vind, at Grundtvig ganske vist ikke efter 1824 hylder tanken om Bibelen som Guds diktat, det, der kaldes verbalinspirationen, men Ole Vind fremfører, at Grundtvig alligevel fastholder, at de bibelske forfattere er "direkte inspireret" af Gud og deres beretninger derfor har karakter af bogstavelig sandhed (Vind 2004).

Ole Vind er formodentlig bevidst om, at hans anklage kommer på et tidspunkt, hvor fundamentalisme-begrebet er aktuelt, og han er formodentlig bevidst om, at han derigennem bryder med det officielle billede af Grundtvig, "Grundtvig-myten" i negativ forstand, i hvilken Grundtvigs virke i bred forstand opfattes i tråd med den almindelige europæiske frigørelsestænkning siden oplysningstiden og som udtryk for det bedste i dansk national identitet, i snævrere forstand som forbundet med Grundtvigs brud med bibelkristendom i 1824-1825. Hvor kommer billedet af Grundtvig som fundamentalisme-kritiker fra? En markant linje i nyere Grundtvigtolkning fremhæver Guds ord ved "Badet og Bordet" som det afgørende i Grundtvigs teologi og fremhæver dermed Guds ord som en levende virkelighed forud for det skrevne Bibelord - der går her en linje fra Anders Nørgaard over Hal Koch til Chr. Thodberg (Pedersen 2003, 154 ff.).

Valdemar Brücker gør sig som "venstre"- eller "ny"-grundtvigianernes mest fremtrædende polemiker til talsmand for en vidtgående accept af bibelkritik, der også inddrager "Geologien og Darwin" (Lindholm 1922, 52) og "læser og bruger af" Bibelen "som af en Bog af Bjørnson" (ibid.).

Begrebet "Bibelkristendom" er introduceret af Holger Begtrup, der i sin forskning netop tematiserer Grundtvigs selvopgør i 1824-25. 
Holger Begtrups synspunkt er her, at Grundvig bryder med bibelkristendommen i 1825, forberedt i de foregående år, hvorefter hans kristendom i 1825 bliver "kirkelig" (Begtrup 1901, 163). Begtrups Grundtvig-tolkning er selvfølgelig ikke blevet til uafhængigt af den strid om forholdet til Bibelen, der prægede årene op imod år 1900, og hvor Valdemar Brücker står centralt.

Går man længere tilbage, kan blandt andet nævnes den strid om Grundtvigs forhold til Luther, der bølger op gennem 1800-tallet ${ }^{6}$. Grundtvig har i det lange stræk været opfattet som værende på afstand af "bibelkristendom". Hvordan kan han så kaldes fundamentalist?

For overhovedet at kunne nå videre med spørgsmålet, er det nødvendigt at indkredse, hvad fundamentalisme er.

\section{Den teologi-historiske fundamentalisme-definition}

I vore dage kaldes som før nævnt både højrekristne, jøder, muslimer og hinduer indimellem fundamentalister. Medens kristne, jøder og muslimer, der betegnes som fundamentalister, alle har tanken om en bog som religionens grundlag som fællesnævner, er det ikke tilfældet med hindu-nationalister i Indien. Alligevel ser man dem beskrevet som fundamentalister i medierne. Det gør det rimeligt at gå både teologisk og profanhistorisk/religionshistorisk/sociologisk til værks og spørge, hvad fundamentalisme er - og om det overhovedet er muligt at bruge begrebet som fællesnævner for de nævnte strømninger.

Det er synspunktet i nærværende arbejde, at det $\mathrm{i}$ en vis forstand kun er rimeligt at bruge begrebet fundamentalisme om den teologiske bevægelse, som opstår i USA i slutningen af det 19. århundrede og i sin første fase markerer sig både i Nord og Syd frem til og med de såkaldte "monkey trials" i USA's bibelbæltestater i 1920'erne, det vil sige retssager om, hvorvidt det var lovligt at undervise $i$ den darwinistiske udviklingslære. Situationen var dengang i slutningen af 1800-tallet, at en liberalteologisk bevægelse kaldet "the Social Gospel" bredte sig i protestantiske kredse i USA (Christensen og Göransson 1975, 445 ff.). Inspireret af tysk liberalteologi forstod bevægelsen for dette "sociale evangelium" kristendommen som moralsk handlen frem for forløsning. Liberalteologi er karakteriseret af et forsøg på at tolke kristendommen uden om, hvad der opfattes som overnaturlige begivenheder: mirakler, opstandelse, tanken om Kristi genkomst. I al liberalteologi indgår der en nytolkning af Jesus-skikkelsen, der bryder med den traditionelle kristendoms billede af ham som sand Gud og sandt menneske, undfanget ved jomfrufødsel, og det var også tilfældet med "The Social Gospel"-bevægelsen. Liberalteo- 
logiens forståelse af Jesus tenderer mod at opfatte ham som et menneske, der gennem sin etik giver de kristne et moralsk forbillede at leve op til - og en sådan opfattelse indgik i den nævnte amerikanske bevægelse. Samtidig bredte den darwinistiske udviklingslære sig, og den historisk-kritiske forståelse af Bibelen gjorde sig gældende. I den situation greb to konservative, evangelikale lægmænd og brødre, oliemillionærerne Milton og Lyman Stewart, til den "Princeton theology", der formuleredes af Charles Hodge (1797-1878) og B. B. Warfield (1851-1921) på presbyterianernes præsteseminarium i Princeton, New Jersey, grundlagt i 1812 med det formål at modarbejde moderne tilløb til at afvige fra klassisk reformert kristendom (Catholic Answers). Dette "seminary" har selv givet et rids af sin historie på en hjemmeside $(<\mathrm{http}: / /$ www.ptsem.edu/About $>$ ), men her med en omhyggelig udeladelse af den strengt konservative fortid - i stedet fokuserer man på, at seminariet blev grundlagt $\mathrm{i}$ en tid, da den højere uddannelse $\mathrm{i}$ USA blev til en egentlig universitetsuddannelse, hvor fagene blev adskilt fra hinanden, og hvor undervisningsinstitutionerne løsnedes fra deres binding til kirkerne, parallelt med, at naturvidenskaberne vandt frem og industrialismen begyndte i øst - et forhold, der gør det nærliggende at se institutionens opkomst som en følge af en tidlig moderniseringsproces. Fundamentalismen opstår imidlertid længere fremme i tiden, og selv om der er tale om en teologisk position, skabtes bevægelsen som sagt af lægmænd, brødrene Stewart, der bekostede udsendelsen af et værk i 12 bind med titlen "The Fundamentals" (1909-10 og flg. år). En lang række veluddannede, men strengt konservative teologer bidrog til værket, inklusive B. B. Warfield. Værket blev trykt i 3 millioner eksemplarer og udsendt gratis til præster, missionærer, søndagsskolelærere og andre. De nævnte "Fundamentals", det vil sige grundlærdomme, er 5 (somme tider 6) principper: 1) Skriftens verbalinspiration, det vil sige, at hvert ord og hver meningssammenhæng i Bibelen har Gud som direkte ophavsmand, den "forfatter", der som Helligånden har dikteret skribenterne ordlyden, 2) læren om Kristi Guddom (inkl. Jomfrufødslen, der somme tider nævnes som et selvstændigt punkt), 3) Kristi stedfortrædende lidelse, 4) Kristi bogstavelige opstandelse og 5) hans bogstavelige genkomst ved tidernes ende - på et tidspunkt har det femte punkt været den bogstavelige karakter af Kristi mirakler. Der er tale om fælles fodslag $\mathrm{i}$ forståelsen af disse punkter. Kun det femte og sidste punkt om genkomsten har været forstået forskelligt af "fundamentalisterne", som deres liberalteologiske modstander Harry Fosdick (1878-1969) kaldte dem. Ved siden af disse 5 punkter er en vigtig læresætning den enkeltes personlige omvendelse - fundamentalismen 
underbetoner sakramenterne dåb og nadver og lægger ved siden af skriften som åbenbaringskilde vægten på den individualistisk forståede omvendelse, Warfield gør gældende, at "The supreme proof to every Christian of the deity of his Lord is in his own inner experience of the transforming power of his Lord upon the heart and life" (Catholic Answers).

Den fundamentalistiske individualisme forbindes dog samtidig i nutidige fundamentalistiske kirkesamfund med en benhård ledelse og disciplin, der ikke tåler afvigelser - den personlige omvendelse er vigtig, men der skal være tale om enshed i omvendelsen! I 1919 dannedes "The World's Christian Fundamental's Association" (Christensen og Göransson 1976, 455 f.), en sammenslutning, i hvis navn begrebet fortsat er knyttet til de 5 læresætninger. Og hvis man valger en stram, klar og umisforståelig definition på fundamentalisme, det vil sige den teologiske fundamentalisme-definition, er disse 5 punkter, hvoraf laeren om Skriftens ufejlbarlighed står centralt sammen med laeren om den personlige omvendelse - der ikke indgår $i$ punkterne - lig med fundamentalisme. Og her er det afgørende, hvilket miljø og hvilken kirkelig sammenhong fundamentalismen er opstået $i$ - at den har presbyteriansk oprindelse, forbinder den med de store "awakenings", de to vakkelsesbølger, som ligger i 1700-tallet og 1800-tallet $i$ USA. Warfields koncentration om individets personlige, subjektive erfaring er en frugt af den omvendelsesreligiøsitet, der fokuserer på den indre begivenhed, hvorigennem individet bliver frelst. Skal man på dette grundlag prøve at sige, hvad der dækker den teologiske fundamentalisme, kan man opstille 7 andre punkter:

1. Den enkelte fundamentalists omvendelse fra sin hidtidige levevis, der ikke var i sand overensstemmelse med religionen.

2. Afvisning af historisk-kritisk læsning af Bibelen - det positive modstykke er:

3. Fastholdelse af verbalinspirationen.

4. Afvisning af forsøg på at fortolke kristendommen på en moderne måde, det positive modstykke er:

5. Fastholdelse af traditionelle kristne læresætninger (de 5 punkter).

6. Afvisning af en videnskabelig verdensforklaring - det positive modstykke er:

7. En fastholdelse af, at Bibelen giver sande svar på spørgsmål som verdens og menneskets oprindelse, svar, hvis sandhed gælder både religiøst og videnskabeligt eller bedre, som verdensanskuelse, således at der ikke skal gives undervisning $\mathrm{i}$ afvigende verdensanskuelser. 
Med denne teologiske fundamentalisme i bagagen gik man til kamp mod teologiske og videnskabelige nytolkninger i det amerikanske samfund. Imidlertid betød den fundamentalistiske offensiv efter sammenslutningen i 1919, at man ikke blot forsøgte at rense de evangelikale kirkesamfund, det vil sige presbyterianere (calvinister), metodister og baptister, for liberalteologi, men også etablerede en række fundamentalistiske bibelskoler og forsøgte at påvirke de enkelte amerikanske stater "til i det offentlige skolevæsen at forbyde en undervisning, der udbredte teorier som udviklingslæren i direkte tilsidesættelse af skriften" (Christensen og Göransson 1976, 456). Kirkehistorikere betoner, at fundamentalismen ikke blot var en indrekirkelig bevægelse, men "en landsomfattende bevægelse, der fandt tilslutning langt ud over de kirkelige kredse" (ibid.), idet man ønskede "at bevare et protestantisk Amerika og bekæmpede ... den ikke-protestantiske immigration, den nye storbykultur og den "secularism", der udbredtes gennem universiteterne og de offentlige skoler" (ibid.), bekæmpede altså sekulariseringen, verdsliggørelsen. Denne kamp, "the Fundamentalist controversy" "stilnede af" "i slutningen af 1920'erne" (ibid., 457), da kirkeledere indså, striden kunne splitte de protestantiske kirkesamfund i nordstaterne presbyterianerne blev virkelig også splittet, men så sent som 1936. Som det fremgår af denne problemstilling, stod fundamentalisterne i vidt omfang $i$ en konfliktsituation $i$ forhold til etablerede teologer inden for kirkerne, også, selv om fundamentalismens modstander var liberalteologiens moderne kristendom. Som sagt blev der lagt låg på konflikterne, og den store depression gjorde det vanskeligt at bruge ressourcer på teologiske stridigheder. Den fundamentalistiske indflydelse forsvandt imidlertid ikke, men fortsatte gennem "de fundamentalistiske bibelskoler" (ibid., 237).

Den stille eksistens, som kendetegnede fundamentalismen fra 1920'ernes slutning og frem, brydes imidlertid efter Anden Verdenskrig, først i 1950'erne (Christensen og Göransson 1976, 464 ff.) og siden omkring 1970 (Catholic Answers), og siden da er bevægelsens indflydelse vokset (ibid.). De tendenser til at påvirke den i princippet ikke-konfessionelle amerikanske statsdannelse, som man ser $\mathrm{i}$ forbindelse med retssagerne om undervisning i Darwinisme $\mathrm{i}$ grundskolerne, blomstrer op på ny. En del af baggrunden er den karismatiske bevægelse: den fokusering på individualistisk religiøsitet, den personlige omvendelse, som præger fundamentalismen i dens første fase, tilføres et nyt element i kraft af karismatikernes fokusering på Helligåndens komme til den enkelte. I begyndelsen kan en liberal politiker som Jimmy Carter nyde godt af at være "born-again- 
Christian" (PBS American Experience), men de amerikanske fundamentalistiske prædikanter indgår $\mathrm{i}$ årene fra $1970 \mathrm{og}$ frem en alliance med højreorienterede politikere, en alliance, der blandt andet omfatter kampen mod fri abort, således som det fremgår af en amerikansk internetsides artikler om emnet. Alliancen har været stærkt fremtrædende $\mathrm{i}$ forbindelse med valget af den nuværende præsident George W. Bush, og man har formodentlig endnu ikke set de sidste fremstød fra den amerikanske fundamentalismes side (PBS Home Frontline The Jesus Factor).

\section{$I V$. Den profanhistoriske fundamentalisme-definition}

Så vidt den teologiske fundamentalisme-definition. Fundamentalismens modsætning er her liberalteologi, bibelkritik og udviklingslære. Som det fremgår, arbejder kirkehistorikere som Christensen og Göransson imidlertid med en forklaringsmodel, der omfatter mere end blot de teologiske stridigheder - der er tale om en reaktion på den modernisering, det amerikanske samfund oplever i kraft af industrialiseringen og urbaniseringen, en reaktion, der altså både er imod videnskabelighed og det opbrud fra en traditionel livsstil, som præger et moderne industrisamfund. Denne reaktion kommer blandt andet til udfoldelse gennem et forsøg på at fundere den amerikanske statsdannelse i evangelikal kristendom og holde de elementer ude Darwinismen - der opfattes som stridende imod den verdensanskuelse, som er begrundet i Bibelens verbalinspirerede ufejlbarlighed. Det er denne samfundsmæssige baggrund for fundamentalismen, der gør det muligt at arbejde med et fundamentalisme-begreb, der ikke i første række er teologisk, men profanhistorisk med inddragelse af sociologiske tilgange til fænomenet. I nærværende arbejde knyttes til ved prof. Uffe Østergård, der på Holocaust-centerets hjemmesider har lagt en tekst ud, der gør opmærksom på fremgangen for "religiøse tolkninger af verden" (Østergård 2001) efter kommunismens sammenbrud. Østergård gør rede for, at en "bogstavtro læsning af hellige tekster ikke blot og bart" er "lig med en religiøs verdensforståelse" (ibid.), og at "religiøs tradition og fundamentalisme normalt står i modsætning til hinanden" (ibid.). Uffe Østergård fremstiller videre, hvordan fundamentalisme forudsætter, at jødedom, islam og kristendom alle er fælles om det træk, "at de sætter Bogen med stort B i centrum" (ibid.). En yderligere forudsætning er nu bogtrykkerkunsten, der medførte reformationen " $i$ takt med at dele af byernes borgere selv fik mulighed for at læse de hellige tekster uden 
præsteskabets medierende og fortolkende mellemled" (ibid.) - et forhold, der hos de til Nordamerika indvandrede "puritanere" førte til, at "de ville vende tilbage til den rene tekst og bestræbte sig på at leve direkte efter Guds ord" (ibid.). Fundamentalisme forudsætter altså "reformationens bogstavtro udfordring" (ibid.) af traditionen, et forhold, der i sin oprindelse hører sammen med protestantisk kristendom og først med den nyeste tids "moderniseringsprogrammer" (ibid.) i den islamiske verden her gør sig gældende, idet det trykte ord udbredes. Østergård gør rede for blandt andet Kemal Atatürks hårdhændede moderniseringsprogram i Tyrkiet, men fremhæver, at på det seneste er moderniseringsprogrammerne "islamisk-fundamentalistiske" og "prøver at omsætte Koranens ord til direkte anvisninger for indretningen af samfundet" - en bestræbelse, som "fænger blandt unge, ofte veluddannede mennesker" (ibid.). Sammenfattende siger Østergård, med tanke på, at også den ikke-bogstavtro hinduisme nu efter hans mening udvikler fundamentalistiske træk:

Fundamentalisme er et følgefænomen til det moderne, samtidig med at den tilsyneladende er på mode. Også blandt mennesker der tilsyneladende kan begå sig i moderniteten. Samtidig med at traditionens modererende indflydelse undergraves af modernitetens permanente revolution, det fænomen vi omtaler som globalisering (ibid.).

Uffe Østergård har med sin påvisning af sammenstødet mellem tradition og fundamentalisme fat i noget afgørende - samtidig med, at den oprindelige fundamentalist-konflikt mellem en - ny - liberalteologi og gammel evangelikal kristendom ikke helt kan passes ind her, eftersom det valgte moderniseringsbegreb ikke ganske er i stand til at fange dennes indre-teologiske problematik. Østergårds iagttagelser kan imidlertid udbygges og suppleres på et afgørende felt: fundamentalisme inden for jødedom, islam og kristendom forudsætter alle en vækkelsesbevægelse, en periode med forsøg på at revitalisere den traditionelle Bog-religion gennem en tilbagevenden til, hvad der bliver markedsført som den oprindelige, bogstavtro religion, altså det fænomen, som Uffe Østergård korrekt forbinder med reformationsbegrebet. For den amerikanske fundamentalisme er det de store vækkelser i det 18. og 19. århundrede inden for de evangelikale miljøer (Christensen og Göransson 1976, 417 ff.). For jødedommen kan der eksempelvis henvises til chasidismen (The Free Dictionary). For islams vedkommende den wahabitiske reform af islam, der er officiel fortolkning i Saudi-Arabien (Wikipedia). Men konflikten i videre forstand mellem modernitet og det, der af fundamentalisterne hævdes at være den gamle tro, samt det forhold, at fundamentalismen forudsætter modernitetens demokratiserende og individualiserende 
træk, er væsentlige iagttagelser. Hvad er det moderne? Med den tyske begrebshistoriske skole kan man pege på de samfundsforandringer, der danner baggrund for det moderne: stigende verdenshandel, urbanisering, videnskabeliggørelse og sekularisering af tænkningen. Afgørende er ifølge nærværende forfatter tre træk: et nyt tidsbegreb, hvor tiden bliver "subjekt" for forandring, den af den nye tidsopfattelse skabte mulighed for at bestemme ikke blot nutiden som bærer af noget kvalitativt nyt, men også fremtiden som en udfoldelse af noget sådant, fremtiden som en åben fremtid, der fremstår som resultatet af fremskridtet som historisk faktor, tanken om menneskets frigørelse fra ydre autoriteter, her først og fremmest religionen og endelig denne frigørelses forbundethed med autonomi-tanken, og derigennem med individet som selvlovgiver. Begreberne Neuzeit og modernitet er forbundne størrelser, idet også modernitetsbegrebet $\mathrm{i}$ én af sine betydningsfulde variationer angiver en afgrænset tidsalder, en periode ${ }^{7}$. Afgørende er imidlertid, at "det moderne" handler om menneskets frigørelse, om den almindelige frigørelse fra forældede samfundsformer og forældede tankestrukturer, som Kants samtidige opfattede som samtalende med det kantiske autonomi-begreb og dermed subjektiviteten som udgangspunkt for tænkning og handling, bevidsthed og fornuft:

Modernitetens iboende princip er subjektiviteten med alt, hvad det indebærer: individualisme, autonomi og ret til kritik. Subjektiviteten er hemmeligheden bag den tendens til opsplitning og differentiering, som måske er det vigtigste overordnede kendetegn ved moderniteten, der allerede afspejles i Kants tredeling af rationaliteten i en teoretisk, en praktisk og en æstetisk fornuft. Den traditionelle énhed af det sande, det gode og det skønne må vige for den irreversible uddifferentiering $\mathrm{i}$ gyldighedssfærerne videnskab (teoretisk fornuft), moral/ret (praktisk fornuft) og kunst (æstetisk fornuft). Subjektiviteten er altså på godt og ondt et kritisk princip, der ikke blot står bag værdisfærernes opsplitning, men samtidig nedbryder det religiøse verdensbilledes magt over sjælene for i stedet at indstifte en dikotomi imellem tro og viden. Dermed er religionens tid selvsagt ikke forbi, men netop som "verdensbillede", det vil sige som meningsgivende og gyldighedsbegrundende autoritet for alle samfundets aktiviteter, lader den sig ikke videreføre (Nørager 1995, 20).

I Nøragers efterfølgende beskæftigelse med og karakteristik af denne uddifferentiering indgår Max Webers sociologi, "I moderniteten har kulturen (...) af sig selv drevet de rationalitetsstrukturer frem, som Max Weber så forefinder og beskriver som værdisfærer", svarende til Kants "tre fornuftsmomenter" (ibid., 253). 
I nærværende arbejde er det et af målene at bestemme Grundtvig i forhold til ikke blot strømninger og positioner i hans samtid, men også hans forhold til de afgørende skift, som kan siges at præge Europas nyere historie, de skift, der i nærværende arbejde overvejende knyttes til tiden mellem 1750 og 1850, den periode, der i den tyske begrebshistoriske forskning betragtes som tiden for det modernes tilblivelse.

$\mathrm{Nu}$ forekommer det nærværende forfatter afgørende for brugen af fundamentalisme-begrebet, at fundamentalismen, som påvist af Østergård, nok er moderne, men samtidig reagerer på det moderne. Men er enhver religiøs reaktion på det moderne nødvendigvis fundamentalisme? Hvilken type moderne tænker man på, det modernes første fase fra 1750 til 1850 eller tiden efter 1850 ?

Som det fremgår, har nærværende forfatter store betænkeligheder ved at anvende fundamentalisme-begrebet, også ved at anvende det over én kam på alle de strømninger, som man i nutiden betegner som fundamentalisme: amerikanske højrekristne, danske konservative kristne, hvoraf ikke alle er tilhængere er verbalinspirationen, ortodokse jøder, islamiske fundamentalister og indiske hindu-nationalister. Når en ellers informativ hjemmeside som Dansk Bibliotekstjenestes på http://www.faktalink.dk (Grøndahl 2001) fremfører, at "Religiøs fundamentalisme har eksisteret, før begrebet opstod" og henviser til profeten Muhammads angivelse i Koranen af blot at være Allahs sendebud, hvorfor Koranen er "Allahs ord" (ibid.), er der grund til mere end skepsis. Man kan betragte islams fokusering på Bogen som direkte åbenbaring som en forudsætning for fundamentalisme, men fundamentalisme både $\mathrm{i}$ den teologiske og den profanhistoriske definition forudsætter en moderne tænkemåde, som fundamentalismen opstår i protest mod - og som det er klart ud fra Østergårds tolkning og den amerikanske fundamentalismes opkomst, indbefatter fundamentalisme oftest, at dens ledende skikkelser selv i kraft af uddannelse og erhverv befinder sig inden for moderniseringen. Og prøver man derfor alligevel, trods betænkelighederne, at bruge begrebet, er der ét markant træk, der forener store dele af disse meget forskellige bevægelser: de tager alle afstand fra sekulariseringen og ønsker i mere eller mindre markant omfang at lade statsdannelsen være religiøst funderet. Dette brud med sekulariseringen er imidlertid ikke en sand fællesnævner: der er grupper, som man almindeligvis betegner som fundamentalister, der blot ønsker at leve i fred og er tilfredse med en sekulær stat, når blot denne ikke forhindrer dem i deres livsførelse: amerikanske amish-mennoniter, for eksempel (Wikipedia). Er de så ikke fundamentalister? Ja, forudsat at man sondrer mellem fundamentalister, der bekæmper statens og offentlighedens sekularisering og 
ad ydre, lovmæssig vej vil forsøge at give staten et religiøst fundament, og fundamentalister, der ikke vil ændre stat og samfund men dog samtidig ønsker at leve som en stat i staten, leve i deres egne enklaver som ikke-sekulariserede samfund med en skole og undervisningstradition, der er baseret på Bogen, den hellige, ufejlbare skrift. Men frem for at tale om fundamentalisme ville det måske være mere meningsfuldt at tale om sekulariserings-modstandere og så begrænse fundamentalisme-begrebet til grupper, der er opstået fra slutningen af 1800-tallet og frem, opstået i forlængelse af en omfattende industrialisering af samfundet, naturvidenskabens dominans fra midten af 1800 -tallet og frem og den liberalteologi, som man finder i slutningen af 1800-tallet og begyndelsen af 1900-tallet.

Men prøver man alligevel at arbejde med et profanhistorisk fundamentalisme-begreb, der har den første bølge i USA 1890 - 1929 med, men især fokuserer på udviklingen fra 1970 og frem, kan der (måske) opstilles en række fællestræk:

1. Fundamentalister har som sociologisk identificerbar gruppe næsten altid, og i hvert fald, når det drejer sig om fundamentalistiske ledere - en moderne baggrund $i$ form af uddannelse og social status, der står i forbindelse med det industrielle og post-industrielle samfund, men de har været igennem en omvendelse, et forløb, hvor de er blevet grebet af den fundamentalistiske vækkelse, der gør dem til redskaber for en af Gud villet fundamentalistisk reform.

2. Fundamentalisterne er med et begreb fra islamisk teologi "Bogens folk" (Islaminfo.dk), jøder, muslimer og kristne kan alene betegnes som fundamentalister, da der her kan arbejdes med begrebet verbalinspiration.

3. Fundamentalister fokuserer i kraft af verbalinspirationen på "Bogen" som eneste autoritet, og vender sig derfor mod traditionel teologi, der indfører traditionen som forudsætning for fortolkningen og dermed i virkeligheden forbereder en historisk-kritisk læsning af "Bogen".

4. Fundamentalister opstår som en reaktion på en sekularisering og dermed en modernisering af en traditionel kultur, en modernisering, som indebærer 4.a en indre historisk-kritisk forståelse af "Bogen" 4.b en ydre reform af samfundet.

5. Fundamentalister ønsker derfor på baggrund af deres egen selvforståelse som ikke-medierende fremstillere af "Bogens" sandheder - det vil sige som de autoritative repræsentanter for og bærere af "Bogens" tilværelsesforståelse og livsstil - 5.a. at reformere den traditionelle religion, føre den tilbage til en 
mere eller mindre fiktiv oprindelighed (se punkt 6!) og 5.b. at reformere en sekulær stat, så den funderes på religion. Derfor tolereres afvigelser fra deres opfattelse af sand religiøs praksis ikke inden for statens rammer.

6. Den tilsigtede fundamentalistiske reform bliver opfattet som en tilbagevenden til en guldalder, en tilstand, der forlægges til fortiden, men i kraft af fundamentalisternes dybe præg af moderniteten ikke kan betragtes som udtryk for reel, stedfundet eller faktuel historisk virkelighed.

Her skal fremstillingen afbrydes med det formål at undersøge, hvorvidt alle 5 karakteristika omfatter de grupperinger eller personer, der arbejdes med. Hvis man tager den oprindelige, amerikanske fundamentalisme, er det tvivlsomt, om der er en direkte sammenknytning med ønsket om at reformere en sekulær stat - om end 1920'ernes gentagne forsøg på at kriminalisere undervisning i udviklingslæren i den amerikanske grundskole må siges at være en indikator for, at amerikanske højrekristne tidligt ønskede en såkaldt kristen stat. Hvis man tager en gruppering som ortodoks jødedom, er det langtfra altid tilfældet, at repræsentanter for denne ønsker at reformere en sekulær stat og gøre den religiøst funderet. Det er således kun nogle af Israels ortodokse, der arbejder på dette - en gruppering anerkender ganske simpelt ikke staten Israel! (Neturei Karta). Vore hjemlige danske konservative kristne deler sig i spørgsmålet om (graden af) verbalinspiration og kan heller ikke uden videre siges at være talsmænd for et ønske om at ændre den sekulære stat til en religiøst funderet statsdannelse (Kronberg 2003) ${ }^{8}$. Selvfølgelig kan man godt finde sådanne træk. Partiet Kristendemokraterne mener, der er en sammenhæng mellem kristendom og politik, og partiet bekæmper den frie abort. Men selv om abortmodstanden er religiøst begrundet, fremstilles abort som mord, og der vises tilbage til en epoke, hvor fri abort var kriminaliseret af den danske sekulære stats lovgivning. Mere betænkelig er ifølge nærværende forfatter visse danske højrekristnes afvisning af udviklingslæren til fordel for en såkaldt "kreationisme", hvor Kristendemokraternes leder Marianne Karlsmose dog har kæmpet for underviseres ret til at forholde sig kritisk til den udviklingslære, man dog redegør for i frie højrekristne undervisningsinstitutioner. Samtidig er der jo ikke tale om, at samfundet som sådan skal indføre undervisning i de højrekristnes "kreationistiske" alternativ til udviklingslæren, men blot om, at nogle grupperinger ønsker frihed til dette (Karlsmose 2002).

Men nu den egentlige genstand for nærværende arbejde, N. F. S. Grundtvig? Er der her tale om, at han - i det mindste i perioder af sit 
liv - falder ind under de 5 punkter? Og kan Ole Vinds "idehistoriske" begreb om fundamentalisme som lig med dét at opfatte Bibelen som historieskrivning og dermed (især) centrale beretninger i Gammel Testamente som fremstillinger af faktuelle, stedfundne begivenheder altså fundamentalisme som lig med en bogstavelig læsning af Gammel Testamente - passes ind i de opstillede skemaer?

\section{$V$. Grundtvigs selvopgør i 1810 og tiden derefter}

Her skal begyndes med Grundtvigs selvopgør i 1810 - det mest afgørende i hans liv, og den eneste begivenhed, han i egentlig forstand opfattede som et brud, det vil sige som en total omvæltning med et radikalt før og efter $(G E, 60)$. I selvopgøret indgår der som sagt en række træk, der er gennemgående i hele Grundtvigs liv og udvikling. Her tænkes på det personlige aspekt i Grundtvigs selvopgør: a) En forudgående periode, hvor Grundtvigs vurdering af sig selv indbefatter hans egen rolle som reformator af kirke og samfund, en tid med høj vurdering af egen betydning; b) denne tilstands omslag $i$ en nedtur med fraværet af varme følelser, kærlighedsevnen og dermed kommunikationsevnen især, det at være i kontakt med sin omverden og fraværet af liv overhovedet, vitalitet som omfattende overskud, kreativitet, inspiration, følelses- og tankemæssig rigdom - også, selv om der sagtens kan være tale om, at Grundtvig oplever en form for isnende, uudholdelig tankeklarhed, et klart syn af sin egen situation som håbløs og især og helt centralt fraværet af egentligt lyssyn, det vil sige en lys betragtning af den øjeblikkelige livssituation og en lys fremtidsforventning præget af håb. Det vil formodentlig stå klart for de fleste, at det er de træk, der kendetegner såvel almindelig melankoli og sortsyn som disses klart sygdomsmærkede side, depressionen; og c) den begivenhed, at denne mørke situation, sammenfattet i død som livets modsætning slår om i c.1), en situation, hvor Grundtvigs rolle som reformator modificeres gennem en fokusering på Guds virke som Helligånd og som forsyn samt den kommende tids udvikling, c.2) genkomst af liv, forstået som kærligheds- og kommunikationsevne, inspiration og kreativitet og c.3) en lys betragtning både af den øjeblikkelige situation og af fremtiden.

Hvis man fastholder Hjalmar Helwegs diagnosticering af Grundtvig som manio-depressiv (Helweg 1932, 53 ff.), vil det være let at sige: en manisk fase afløses af en depressiv fase, der så igen afløses af en form for mere realistisk vurdering af egen situation. Men det er påfaldende, at dette trefasede forløb kan identificeres hos Grundtvig både i livssituationer, der er klart sygdomsmærkede, og i livssitua- 
tioner, hvor en psykiatrisk diagnose af Grundtvig som syg vanskeligt kan komme på tale?

I fremstillingen af det personlige trefasede udviklingsforløb er der med vilje set bort fra de enkelte selvopgørs konkrete træk, og det er heller ikke blevet forsøgt at sætte dem ind i en teologihistorisk sammenhæng - til selvopgørene i 1810 og 1823-24 lægger sig eksempelvis, hvis vi følger linjen bagud, den omvæltning, forelskelsen i Constance Steensen de Leth medførte i 1805-1808 og i linjen fremefter eksempelvis Grundtvigs depression i 1843-44 og det efterfølgende vendepunkt i forbindelse med julen 1845. Det nævnte trepunkts-skema skal forstås idealtypisk (Eriksson 1986, 13) - der er - selvfølgelig afvigelser i de konkrete forløb, for eksempel går en livløs tilstand forud for Grundtvigs reformator-drømme i 1810, en livløs tilstand, der samtidig ikke direkte identificeres som melankolsk af Grundtvig.

Men nu er det 1810 og 1823-24, der står i centrum. Her skal gribes fat $\mathrm{i}$ både det teologihistoriske og det konkrete $\mathrm{i}$ forbindelse med begivenhederne i 1810. Det gælder her, at Grundtvigs selvopgør rent teologisk kan og skal forstås som en klassisk omvendelsesoplevelse i forlængelse af den individualistiske vækkelseskristendom, som præger 1700-tallets lutherske pietisme. Og når det gælder begivenhedens konkrete træk og betydning i Grundtvigs liv, er det som før nævnt rimeligt at sige, at der - uden for al diskussion - er tale om den mest afgørende og skelsættende begivenhed i Grundtvigs liv. Uden $1810 \mathrm{var}$ hans liv blevet et andet, og Danmarks kirke- og kulturhistorie havde set grundlæggende anderledes ud.

Situationen er, at Grundtvig som en følge af forelskelsen i Constance er kommet på bølgelængde med sin tid. Den rationalistiske kristendomsopfattelse og fascination af det sene 1700-tals livsholdninger og æstetik, som præger ham, da han ankommer til Egeløkke, er nu blevet afløst af en fokusering på digtningen som en budbringer fra evigheden, digteren som geniet, der forbinder denne evige verden med det timelige og en æstetik, hvor romantikkens fokusering på digtning som båret af billedsprog, og dermed som det flertydige symbol, der lader evigheden komme til syne i dunkle glimt, er det afgørende. Et centralt tema i disse år er også kærligheden, idet Grundtvig lader digterens sublimerede kærlighedsevne være redskabet for dennes status som medium for det evige. I de følgende år er Grundtvig fascineret af religiøsitet og ikke mindst Asatroen, den gamle, nordiske hedenske gudetro. Ved hjælp af blandt andet Schellings skrift om religion og filosofi fra 1804 fortolker Grundtvig Asalæren som et enkelt digtergenis billede af evigheden i forhold til tiden. Forskningen har været noget uenig i spørgsmålet om, hvorvidt Grundtvig i disse år 
ser sig selv som en repræsentant for en almen religiøsitet, der sidestiller Asalære og kristendom, eller om han gradvis arbejder sig frem til en forståelse af sig selv som kristen ${ }^{10}$. F. C. Sibbern gør det klart, at "Man sagde dengang om Gr., at hans Tro var Asatroen, hvilket naturligviis ei var saa" (GE, 117-118). Spørger man Grundtvig selv, siger han $\mathrm{i}$ et af sine tilbageblik på sit liv og sin udvikling, at han $\mathrm{i}$ tiden umiddelbart inden begivenhederne i 1810 opfattede alle religioner som mytologi i betydningen jordiske udtryk for det evige, men betragtede kristendommen som den højeste form for mytologi. Grundtvig skriver, at han "antog Christendommen for en reen, uforfalsket Fremstilling af det Aandelige" ( $G E, 61)$, "Idealet for alle Mythologier" (ibid.). Grundtvig er i sin "mythologiske" (ibid.) periode.

$\mathrm{Nu}$ sker det, at Grundtvig i vinteren 1810 af sine forældre bliver bedt om at komme hjem og aflaste sin gamle syge far som personel kapellan, således at faderen kan forblive i embedet. Grundtvig svarer, at han kan gøre "langt bedre fyldest $i$ hovedstaden end $i$ en afkrog af landet" (Kofoed 1954, 107), ja at han ønsker at forblive i hovedstaden som "Ungdomslærer og Skribent" (ibid., 108), det vil sige lærer på Schousboes Institut og forfatter. Grundtvig vil gøre karriere, og han har al mulig grund til at tro, det lykkes! Alligevel holder han sin berømte dimisprædiken 19. marts 1810 med titlen "Hvi er Herrens Ord forsvundet af hans Hus?". Titlen lægger op til, at Grundtvig træder frem som fornyer af gammeldags kristendom i en rationalistisk samtid, som Grundtvig siger i Kirke-Speil "et lidenskabeligt Udbrud af et gammelluthersk Brushoved" (ibid., 15). Hovedtanken er kristendommens betydning for "Videnskaberne" (ibid., 110) og trods titlen følger Niels Kofoed Grundtvigs dom, når han 1815 skriver, at han endnu ikke havde afgjort sig i forhold til spørgsmålet: "er Tro paa Guds Ord kun for Moralitetens og den indvortes Roligheds Skyld de mindre begavede Aander aldeles nødvendig, eller trænge alle uden Undtagelse til den?" (ibid., 114), det vil sige: skal kristendommen forstås rationalistisk med Kant som en hjælpeforestilling for moralsk handlen, eller er den den eneste frelse for syndere $?^{11}$ Konflikten med forældrene fortsætter, og man må antage, at den piner Grundtvig. I denne situation læser han i sommeren en række historiske værker, blandt andet den tyske forfatter A. H. L. Heerens bog om korstogene og den schweiziske forfatter Johannes Müller, af hvilke Grundtvig lærer at se bort fra sine lutherske fordomme om middelalderpaverne og at vurdere tanken om paven som "Christi Statholder" (Michelsen 1956, 67), og så endelig den tyske forfatter Kotzebues preussiske historie. Samtidig ønsker Grundtvig at vise "sit Folk" (ibid., 68), at Vedels 
Saxo-oversættelse er den rette, han ønsker altså at spille en rolle i forhold til den danske nation. Kotzebue skildrer, hvorledes kristendommens "visne Kors" plantes i Preussen som erstatning for hedenskabets grønne eg. Grundtvig, der altså vurderer kristendommen højt som den "endelige" åbenbaring af det guddommelige og må betragtes som præget af kristen monoteisme farvet af idealistiske elementer, oprøres og ledes derved frem til en opfattelse af sig selv som reformator, i Kirke-Speil skriver han herom, at der her i "Efteraaret" "fulgte et Par Maaneder af stolt men stille Sværmeri" $(G E, 94)$. Sværmeriet kommer til udtryk i Grundtvigs tolkning af Johannes' åbenbaring. Afgørende er den følgende sammenhæng: "Nu saae jeg Kristendommen overalt som i Norden betegne (...) Folkenes Liv og dens Synken deres Død..." Grundtvigs selvopfattelse som et redskab for kristendommens genrejsning kommer til udtryk i en særegen tolkning af de såkaldte "Sendebreve" i Johannes Åbenbaring kap. 1-3, de syv breve, der gennem adresseringen "Skriv til Menighedens Engel i ..." er stilet til syv menigheder i syv byer i antikkens Lilleasien. Grundtvig gennemfører, hvad man kalder en "kirkehistorisk" (Mosbech 1934) tolkning af sendebrevene, idet han følger en stærk tradition for at forstå ordene om hver af de syv menigheder som profetiske spådomme om kirkesamfund, der skal komme i kristendommens historie. Det afgørende er, at hver af de syv folkemenigheder, som sendebrevene ifølge Grundtvig omhandler, bliver til som følge af en reformation, det vil sige en reaktion på dén kristendommens forfaldssituation, der præger menighedernes udgangsposition. Og hver menighed har en 300 -årig periode, der indledes med dens reformatoriske tiltag og afsluttes med forfaldet - det forfald, som den næste menighed så bekæmper. Lige så vigtigt er det, at hver af disse folkemenigheders reformerende tiltag sættes i gang af et enkelt individ, den "Menighedsengel", som for Grundtvig er Guds udvalgte redskab til fornyelse af kristendommen. Og selv om Grundtvig - som det fremgår af den allerede inddragne "Lidet om Jesu Christi Aabenbaring" - ikke betragter sig selv som en sådan reformator, betragter han sig, i lighed med forholdet mellem Johannes Døberen og Jesus, som reformatorens forløber, et forhold, Grundtvig ser eksemplificeret i historien gennem Johan Huss som forløber for Martin Luther. Grundtvig opfatter sig selv som et individ, der er udset til at forberede den kommende reformators virke. Ifølge nærværende forfatter har man her kilden til Grundtvigs fascination af Johannes Døber-skikkelsen, Døberen som dén, der mange år senere gør folkeligheden rede til at modtage kristendommen - et forhold, der bekræftes af, at Grundtvigs kirkehistoriske tolkning af sendebrevene er 
konstitutiv for hele hans tankeverden og kan findes på tværs af alle de selvopgør og faser, der præger forfatterskabet ${ }^{12}$. Afgørende er her, at Grundtvig opfatter sig selv som et led i Guds virke med henblik på kristendommens genrejsning i Norden. Med Niels Kofoeds ord er 1810 "den tid, da Gr. efter egne ord "fik Øie for Kristendommens Nødvendighed for Folkenes Historie"”, men Kofoed føjer til, at "herfra er der igen et langt spring til personlig omvendelse" (Kofoed 1954, 116).

Hvad sker der så videre i Grundtvigs liv i disse afgørende måneder? Grundtvig har selv mange år senere skildret begivenhedsforløbet $\mathrm{i}$ Kirke-Speil (GE, 86-112), men man gør selvfølgelig klogt i med Niels Kofoed at rekonstruere begivenhederne ud fra samtidige dokumenter. Konflikten med forældrene tilspidses fra slutningen af november, da Johan Grundtvig har fået bevilget afsked. Grundtvig ved, blandt andet fra sin mors brev, hvor hun bebrejder ham hans "feige Sindelag, der foretrækker Lyst for Pligt" (Kofoed 1954, 108), hvad forældrene tænker derom. Kofoed skriver herom: "Der er ingen tvivl om, at Gr. byggede sine reformatortanker op som et værn mod sit afslag til forældrene" (ibid., 119), og fortæller videre, at "En morgen midt $\mathrm{i}$ december blev Gr. liggende i sin seng paa kollegiet" (ibid., 120), hvorefter hans morbroder, den pietistiske professor i medicin F. L. Bang, tilkaldtes, men ikke kunne eller ville stille noget op, da Grundtvig efter hans mening lå "i indvortes kamp for sin sjæls frelse" (ibid., 120). I en uges tid lå Grundtvig til sengs, talte i vildelse og havde hallucinationer - afgørende er med Kofoeds ord, at "Det er hjertekulden, der nager hans sjæls inderste. Den dybe følelse af tilværelsens intethed og ensomhedens pinefulde byrde strømmer igennem ham" (ibid., 121), Grundtvigs hoved og hjerte ligger i strid, "Han angrer sine synder med hovedet, men hjertet vil ikke følge med" (ibid., 122). Efter en uges tid falder Grundtvig til ro, og Sibbern ledsager ham til Udby. Undervejs oplever Sibbern, hvorledes Grundtvig føler Djævelen som en slange sno sig om hans krop - men i Udby, at faderen, Johan Grundtvig, ligesom F. L. Bang tolker Grundtvigs oplevelser teologisk med ordene "Min Søn har Anfægtelser" (ibid., 123). Allerede i begyndelsen af januar er Grundtvig i stand til at indgive ansøgning om at blive faderens kapellan, og det bevilges. Da Grundtvig har fået krisen godt på afstand, skriver han til Waldemar Østrup og fortæller om forløbet. Grundtvig skildrer, hvorledes han "aflagde (...) Alt, hvad [ham] tyktes uchristeligt at være undtagen Hovmoden" ( $B G \mathrm{I}, 39)$, hovmoden, som "indbildte" ham, at han var "en hellig og gudtækkelig Mand, hvem Han havde valgt til at føre Kristendommen paa Fode igen" (ibid.). Grundtvig skildrer videre, 
hvorledes hans "Forstand gruede, men Hjertet vedblev at være haardt og koldt" (ibid., 39). Afgørende er, at Grundtvig selv forbinder sin vej ud af krisen med sin ordination og pinsen - et forhold, der bekræftes af Chr. Thodbergs arbejde med Grundtvigs "Skov-oplevelse" i Grundtvig-Studier 1987, hvor Grundtvig føler sig styrket af Helligåndens nærvær (Thodberg 1986, 11 ff.). Af brevet synes det, som om Grundtvig gennem denne ydmygelsesoplevelse opgiver sine reformatortanker. Men kun to år senere udsender Grundtvig sin berømte første Verdens-Krønike, hvori hovedtanken er, at "Et Folks Bedrift maa have været og blive en Frugt af dets Tro" (US II, 177). Dette udsagn gælder principielt alle former for tro, men det er Grundtvigs hensigt at vise, hvorledes kristendommen beviser sin status som den eneste sande tro gennem sine virkninger i historien, og afgørende er, at Grundtvig under udarbejdelsen af verdenskrøniken underrettes om den lutherske teolog F. V. Reinhards død og dermed opfatter det 300-årige lutherske tidsrum som afsluttet, hvorefter et nyt begynder - med Sigurd Aa. Aarnes' ord er forholdet det, at i Grundtvigs "Allehelgensdagspreken" i Udby kirke 1812, hvor Grundtvig efter evangeliskluthersk skik taler om Luther, er "paralleliseringen mellom tiden ved Luthers fremtreden og samtidssituasjonen...tydelig" (Aarnes 1961, 99). Grundtvig har siden 1810'erne opfattet sig selv som et pant på og forbillede for Danmarks udvikling. Selve dagnings-motivet, tanken om fornyelse, har stået centralt i hans bevidsthed. Dette er baggrunden for Fl. Lundgreen-Nielsens analyse af Grundtvigs "selvsymbolik": "se jeg stander som et Tegn, / For en Blomster-Tid i Norden" (LundgreenNielsen 1980, II, 716 ff., 883 ff.). Grnndtvigs hovedtanke med skildringen af det lutherske tidsrum som præget af en stigende sekularisering og derfor af et voksende forfald fører frem til den "Lægedom" (Aarnes 1961, 110), som alene er at finde i Bibelen. Når Grundtvig i det førnævnte tilbageblik skal karakterisere denne sin "theologiske" $(G E, 62)$ periode, gør han det klart, at "al min Skrift, fra den Tid, dreier sig om enfoldig Troe paa Skriften, som et aabenbart Guds Ord, og den deraf flydende Troe paa Jesum Christum, som det eneste Saligheds-Middel for syndige Mennesker" (ibid.).

Samtidig fortæller Grundtvigs breve til samtidige som J. P. Mynster om hans selvfølelse, hans forståelse af sin rolle som en forkynder, der kalder Danmark tilbage til kristendommen.

Grundtvig betragter altså i årene efter 1810-1811 og frem Bibelen som Guds klare, umisforståelige tale, og han vender sig mod rationalistiske teologer og idealistisk påvirket religiøsitet - en krig, der dog $\mathrm{i}$ Grundtvigs "historiske" periode 1816-1821 føres indirekte gennem hans bestræbelser på at vise, hvorledes historien vidner om kristen- 
dommens sandhed. Et erindringsglimt vidner om, at han ikke blot betragter Skriften som åbenbarende Gud, men at han også hylder tanken om verbalinspirationen, Daniel Peter Smith fortæller, hvorledes Grundtvig forsvarer den tanke, at "hvert Ord i den ganske hellige Skrift [er] indblæst af Gud, 'dicteret af den hellige Aand'" $(G E, 124)$. Grundtvigs appel til samtiden om at vende tilbage til kristendommen er bestemt af læren om verbalinspirationen!

Endelig skal det fremhæves, at Grundtvigs accept af verbalinspirationen fører ham til at benytte Bibelen som argumentation mod en videnskabelig verdensforklaring. Grundtvig forkaster det copernikanske verdensbillede, således som det fremgår af et avisindlæg i Nyeste Skilderie af Kiøbenhavn (II årg. 1814, 1140-42) og af Verdenskrøniken fra 1817 (VK 1817, 196). Et yderligere argument for Grundtvig er, at den danske astronom Tyge Brahe var kritisk over for Copernikus, men grundlaget for Grundtvigs afvisning er dybest set et ønske om at fastholde det verdensbillede, som Gammel Testamente er tænkt ind i, samt et ønske om på dette grundlag at skitsere en alternativ naturvidenskab, der er i overensstemmelse med Bibelen og vel dybest set udledes af denne.

VI. Redegørelse for de personlige trck $i$ Grundtvigs selvopgør og teologihistorisk indplacering og vurdering af Grundtvigs omvendelse i perioden 1811-1824

Her skal fremstillingen midlertidigt standses for at holde denne Grundtvigs udvikling sammen med forst de fællestræk, som er blevet identificeret i hans selvopgør, dernæst de teologihistoriske forlæg, der kan findes, og endelig de to fundamentalisme-definitioner, jeg arbejdede mig frem til ovenfor.

Først er der blot at konstatere, at det treleddede skema a) - b) - c) gælder for begivenheden. Grundtvig ligger først i dvale, så kommer en optur med stolt sværmeri, derefter en nedtur med fravær af liv og endelig modifikationen af Grundtvigs forståelse af sig selv som reformator gennem en fokusering på noget uden for Grundtvig, nemlig Helligånden og dens virke - dét virke, der altid for Grundtvig forudsætter noget ydre, sakramenterne eller, som her i 1810-1811, håndspålæggelsen ved ordinationen, som Grundtvig endnu i Den christelige Børne-Lardom tillægger virkekraft (US IX, 570-571) men vel at mærke virkekraft uafhængigt af bispeembedet som båret af den apostoliske succession.

Dernæst skal det slås fast, at selv om Grundtvig i brevveksling med J. P. Mynster sidestiller "Pietisme" med "ugudeligt Spil" ( $B G, \mathrm{I}$, 
99) og i øvrigt livet igennem stillede sig meget fjendtligt an i forhold til hernhutterne ${ }^{13}$, indgår der klare pietistiske træk $i$ hans omvendelsesoplevelse - med Grundtvigs egne ord til Stenersen er der tale om at han gennem 1810-oplevelsen når til at "korsfæste Hovmoden" og "angrende bekende" sin "gruelige Fordærvelse", "Sønderknusende tilstaa" sin "hjelpeløse Elendighed" og "sætte" sin "Lid til den ringe Mand, der regnedes blandt Misdædere" $\left(B G\right.$ I, 247) ${ }^{14}$. Pietismen glider her sammen med den lutherske ortodoksi, der er tale om "Omvendelse" (ibid., 39, 273) forårsaget af lovens anden brug, dens dom over synderen, der leder ham til "den faste Tro, den inderlige, kiærlige Følelse af (...) [Guds] Helligaands Samfund" (ibid., 274). Set i dét perspektiv er Grundtvig en del af de store vækkelser, der optræder i Europa og USA efter oplysningstiden og Napoleonskrigene, de vækkelser, der over for den rationalistiske oplysningsteologi stræber mod at vende tilbage til traditionel kristendom - og samtidig er Grundtvig, i lighed med det presbyterianske "seminary" i Princeton, en del af teologiens svar på den moderniseringsbølge, der hører med til modernitetens første fase, og som nævnt ovenfor har sit filosofiske udtryk i Immanuel Kants tænkning og sin basis i den tidlige industrialisering, urbanisering og verdenshandel.

I forlængelse af denne teologihistoriske tolkning af Grundtvig skal det endvidere blot konstateres, at påvirkningerne fra luthersk ortodoksi og pietisme hos Grundtvig suppleres af en tilslutning til læren om verbalinspiration samt - meget afgørende - en afvisning af den moderne naturvidenskabs verdensbillede. Men er Grundtvig så ikke - i hvert fald i denne periode, det vil sige 1810 til 1824 - fundamentalist, som Ole Vind mener? Jo, det er tilfældet, hvis man alene benytter den første, teologiske definition på fundamentalisme, som blev fremlagt: Grundtvig har 1) været gennem en mere eller mindre pietistisk omvendelse, 2) han afviser en historisk-kritisk tilgang til Bibelen, 3) han fastholder verbalinspirationen, 4) han afviser en moderne tolkning af kristendommen, 5) han fastholder over for rationalisterne den traditionelle kristendom, og han ville sagtens have kunnet tilslutte sig fundamentalisternes 5 punkter, 6) han afviser en videnskabelig verdensforklaring, og han 7) mener, at der på bibelsk basis kan udarbejdes en form for videnskabeligt alternativ til naturvidenskabens verdensbillede.

Så langt, så godt. For fortsætter man med den profanhistoriske fundamentalisme-definition, ser billedet noget anderledes ud. Her kan 1) Grundtvig vanskeligt indrulleres under den gruppe af "moderne" uddannede intellektuelle, mennesker med uddannelser, der er relateret til det industrialiserede og post-industrielle samfund, mennesker, der 
gennemløber en fundamentalistisk "omvendelse". Grundtvig hører hjemme i en anden tid, i modernitetens første fase fra 1750 til $1850-$ og hans modernitetsbegreb kan læses frem gennem analyser af hans nuancerede stillingtagen til Kants autonomibegreb! ${ }^{15}$ At han 2) i tiden efter $1811 \mathrm{og}$ frem til 1824 er tilhænger af verbalinspirationen og 3) med sin kamp mod oplysningsteologien og i den forbindelse også de kirkelige autoriteter vender sig kritisk mod de traditionelle teologiske læreinstitutioner og 4) ønsker at reformere teologien, er ikke tilstrækkeligt til at karakterisere ham som fundamentalist, for Grundtvig ønsker 5) ikke en tilbagevenden til en idealiseret guldalder - i Grundtvigs tanke om folkemenighedernes progression, dét, at den ene afløser den anden, ligger en historisk tænkemåde gemt, der præges af tanken om, at de forskellige folkemenigheder rummer forskellige træk. At tænke forandringen er moderne, og i den forstand er Grundtvig præget af moderniteten.

Grundtvig er altså ikke fundamentalist, hvis fundamentalismebegrebet iklædes historisk skikkelse og da så at sige tidsfæstes til tiden efter 1850. Og kun dér giver det for nærværende forfatter mening. Den vækkelsesprægede reaktion på oplysningsteologien, rationalismen, som i 1800-tallet findes i hele den protestantiske verden (og vel har sit sidestykke i den katolske ultramontanisme, altså den relancering af paveembedet, som finder sted efter Napoleonskrigene, se Christensen og Göransson 1976, 40 ff., 85 ff.), er ikke uden videre fundamentalisme, heller ikke selv om de fleste af dens repræsentanter arbejder med en verbalinspirations-lære. For at der kan blive tale om fundamentalisme, må man arbejde med en reaktion på den gennemgribende modernisering, industrialiseringen og urbaniseringen fører med sig, og helst også med den fremtrædende plads, naturvidenskaben får i tiden efter 1850. Men så Grundtvig efter 1824 da? Det er Ole Vinds påstand, at netop dén Grundtvig, der fra 1833 udarbejder Haandbog $i$ Verdens-Historien præges af en fundamentalisme, der forbinder en bogstavelig forståelse af centrale Bibelsteder med nationalistiske træk. Hvordan i alverden kan det passes sammen med Grundtvigs "kirkelige Anskuelse" (US IX, 49), hvor ikke Bibelen, men de levende ord ved dåben og nadveren er kristentroens grund?

VII. Den "kirkelige Anskuelse" som vendepunkt $i$ Grundtvigs forståelse af Bibelen

Her skal først arbejdes med Grundtvigs "kirkelige Anskuelse", hvorefter Haandbog $i$ Verdens-Historien inddrages. Den kirkelige anskuelse står i forbindelse med Grundtvigs opdagelse i 1825, der 
siger så meget, at ikke skriften, men Guds "levende ord" ved dåb og nadver, her først og fremmest den apostoliske trosbekendelse, er kirkens og kristendommens grundlag, og at skriften skal lægges "paa Alteret" (US IV, 547), altså læses ud fra det levende ord? Betyder denne "mageløse Opdagelse", som Søren Kierkegaard sarkastisk kaldte den (Garff 2002, 197), ikke et brud med al fundamentalisme? For at kunne besvare dette er det nødvendigt ikke blot at se på Grundtvigs egne tekster, men også på fortolkningen af dem gennem tiderne.

To markante Grundtvig-fortolkere har i tiden efter Anden Verdenskrig hver for sig arbejdet med Grundtvigs opdagelse i 1825 og især med dens forhistorie: først Kaj Thaning og senere Christian Thodberg. De er temmelig uenige, men har også påvirket hinanden, og de har som udgangspunkt og forudsætning ét afgørende fællestræk: den dialektiske teologis understregning af "Guds ord" som tilsigelse og forkyndelse, som den sætter sig igennem i Karl Barths og senere Rudolf Bultmanns teologi i tiden efter Første Verdenskrig og frem. Thanings og Thodbergs Grundtvig-tolkninger kan hver for sig forstås som en fortolkning af Grundtvig på baggrund af "Guds ord"-teologien, et forhold, der blandt andet står i forbindelse med Anders Nørgaards Grundtvig-læsning i mellemkrigstiden, hvor barthianismen bestandig var hans samtalepartner og negative forudsætning. Thaning og Thodberg mødes i en optagethed af "Guds Ord" (Thyssen 1997, 66 ff.). Thanings og Thodbergs Grundtvig-tolkninger kan - når det drejer sig om nærværende tema, ord og skrift - ydermere forstås ud fra Grundtvigs egen skelnen mellem "de to spørgsmål, der ikke måtte sammenblandes: "Hvad er den sande Christendom d.e. hvad har Christus lært? Og: er Christendommen sand d.e. er Christus troværdig?" (Thaning 1981, 7). Det første spørgsmål handler om, hvordan den kristne kan nå til vished om, hvad der oprindelig og fremover har været betragtet som sand kristendom - her står en historisk spørgen altså i centrum. Det andet spørgsmål handler om det eksistentielle - er kristendommen sandhed, er den frelse for mig, er det i den, jeg kan få mit spørgsmål om mit livs mening besvaret? Både Thaning og Thodberg fokuserer klart på det sidste - samtidig med, at Thaning også tilkender det første spørgsmål værdi og betydning, blot det ses som uløseligt forbundet med og en følge af det sidste, eksistentielle - et forhold, Grundtvig selv havde blik for "På sine gamle dage" (ibid., 29). Begge fortolkere er også opmærksomme på det lange udviklingsforløb, der fører Grundtvig frem til opdagelsen i 1825 , et udviklingsforløb, der, når det gælder den "nære" historie, omfatter årene 1823-1824-1825 og i et videre forløb 1830'erne - 
Thaning fremhæver 1832, Thodberg årene omkring 1837, den "græske vækkelses" og Sang-Voerkets tid.

Kaj Thaning har ikke blot analyseret Grundtvigs syn på Guds ord i sin monumentale disputats Menneske først fra 1963, men også i en række andre vægtige arbejder. I 1953 gennemfører han i GrundtvigStudier 1953 en omfattende analyse af Grundtvigs forhold til Irenæus, en analyse og fortolkning, som al senere Grundtvig-forskning har levet af. Thanings landvindinger er godt opsummeret af Bent Christensen, der med Thaning fremhæver, at Irenæus-påvirkningen slår igennem i Grundtvigs forfatterskab fra og med Midfaste Søndag 1823 (Christensen 1987, 17 ff.), hvilket stemmer med Grundtvigs egen angivelse af, at det var dette år, han indledte sine Irenæus-studier (Schjørring 1990, 104 ff.). Hvilke træk forbinder Grundtvig med den gamle kirkefader?

For det første menneskesynet, det vil sige tanken om mennesket som skabt i Guds billede, men af Djævelen forført til ulydighed, ikke syndens ven, men dens slave, og i tråd hermed Kristus som den anden Adam, der optager det faldne menneske i sig og forløser det i en forløsning, der omfatter hele mennesket og hele skaberværket (Christensen 1987, 17). I nærværende sammenhæng er det vigtigt, at den fokusering på skabelsen og mennesket som skabt, der allerede er fremme i Danne-Virke-tiden, styrkes. Skabelsestanken gør det muligt for Grundtvig at forholde sig åbent til sin samtid, og dermed også at indlede det kultursamarbejde med naturalisterne af ånd, som signaleres i Nordens Mythologi 1832 og reelt indledes fra slutningen af 1830'erne (Thyssen 1983, $250 \mathrm{ff}$.). Skabelsestanken udfoldes i forbindelse med menneskets lighed med Gud i henseende til det levende ord og kærligheden som grund-egenskab.

For det andet kirkesynet: Grundtvigs prædikener bevæger sig i 1823 og 1824 frem mod 1825 "ad to spor" "en stadig dybere forståelse af Kirken som Guds folk, Kristi menighed, ja Guds hus, Guds bolig hos os her og nu, for det andet et spor, der betegner en søgen efter noget umiskendeligt, hvorpå ven som fjende kan kende kristendommen" (Christensen 1987, 28) ${ }^{16}$. For at få grundigere greb om dette er det imidlertid nødvendigt at kaste et blik på Grundtvigs udvikling fra $1823 \mathrm{og}$ frem, således som den er skildret af Kaj Thaning. Thaning tager sit udgangspunkt i den begivenhed, Grundtvig selv skildrer $\mathrm{i}$ fortalen til Nyaars-Morgen - dels det forhold, at Grnndtvig ved afslutningen af sit arbejde med oversættelserne af Snorre og Saxo "følde med Gru, hvor død (...) [han] var blevet" og "ogsaa legemlig" "følte" sig "Graven nær" (Nyaars-Morgen, 12), men at Gud gav ham "Mod" til at bekæmpe "Døden" i sig og omkring sig "med 
Opstandelsens Haab" (ibid., 12-13) da han i 1821 kaldtes til præst i Præstø og siden i 1822 ved Vor Frelsers Kirke i hovedstaden hvorefter det afgørende så skete, at han "Som Præst" "siden KirkeAarets Begyndelse" i advent 1823 følte, "at Natten (...)[er] forgangen og Dagen kommet noer" (ibid., 14). Thaning agter ikke Grundtvigs tekst, men skriver, at "Som Prædiken er dette Adventsprosadigt (...) ikke meget bevendt" (Thaning 1953, 9) og gør det klart, at indholdet blot er en bebudelse af, at der "snart vil blive Lys i Stedet for Mørke i Menigheden!" (ibid.,). Alligevel tidsfæster Thaning et "Gennembrud" (ibid., 10) til denne adventssøndag, et gennembrud, der står i forbindelse med Grundtvigs Irenæus-læsning dette år og med en understregning af Helligåndens skabende kraft, 2. juledag prædiker Grundtvig om Helligånden, der kalder, forsamler og levendegør "Menigheden 'til Dagenes Ende"' (ibid., 14), og Thaning føjer hertil, at Grundtvig under "Selvopgøret", som igangsættes af Irenæuslæsningen "slidsomt" "maa kæmpe sig frem til ny Klarhed over den tredje Trosartikels Betydning" (ibid., 14), en erkendelse, der også kommer til udtryk her i 1820'ernes midte før "opdagelsen” på 22. søn. e. trin. 1823 (ibid., 43). Thaning fremfører derfor, at Grundtvigs nybrud, den nye periode i hans liv, indledes i 1821 og 1823, hvor "hans Veje" begynder "at klare sig" (ibid., 19), en afklaring, der, som det fremgik, af Thaning skildres ved hjælp af gloserne "Gennembrud" (ibid., 29) og "Selvopgør" (ibid., 36), også selv om selvopgøret ifølge Thaning ikke føres til ende. Blandt de mange spændende prædikener, som Thaning analyserer, fremdrages i nærværende artikel adventsprædikenen, dels fordi Grundtvig selv tillægger den betydning, dels fordi Thaning fokuserer på denne som udtryk for et nybrud, det nybrud, der står i forbindelse med Grundtvigs indsigt i, at "Herrens Menighed" "fra Begyndelsen" "stod" og "skinnede som et Lys i Mørket i en Verden som elsker Mørket mere end Lyset", og "saaledes skal den staae til Verdens Ende til Evighedens Dag" (GP II, 28), og at netop dette forhold er et pant på, "Dagens Komme" (ibid.,). Thaning peger foruden på Irenæus også på Grundtvigs optagethed af fætteren Henrik Steffens' hjemgang til luthersk kristendom og gør det klart, hvordan et menneskesyn med en positiv forståelse af menneskets skabthed er tvundet sammen med Grundtvigs nye kirkesyn, "Steffens' Fremhævelse af Menigheden" (Thaning 1981, 38) medfører hos Grundtvig "Synet af Kirken gennem Tiderne, Kirken, der jo ogsaa var før Luther" (ibid., 37). Sammenfattende siger Thaning, at Grundtvig i "1822-1823" er "naaet frem til sit Menighedssyn og til det nyfødte Bibelsyn, hvorigennem Ordene er blevet levende og Aanden har opvakt 'det kun skindøde Bogstav"' (ibid., 47), der er tale om 
nyvunden "Klarhed" (ibid., 49), der også fører til en svingning i Grundtvigs "Sindsstemning" (ibid.,) - og som dybest set, også når det gælder kirkesynet, står i forbindelse med Grundtvigs opdagelse af det menneskesyn, Irenæus er talsmand for. Thaning skildrer videre, hvorledes Grundtvig i vinteren 1823-1824 "skriver (...) sig igennem et af sit Livs Selvopgør og til sidst i Nyaars-Morgen [når] til et afklaret Tilbageblik over sit Livs Stadier" (ibid., 51). Imidlertid har Thaning behandlet 1824 mere grundigt andetsteds.

Til den tidlige afhandling om Grundtvig og. Irenæus lægger sig således Thanings ovenfor inddragne alderdomsarbejde om den kirkelige anskuelses tilblivelseshistorie i Grundtvig-Studier 1981. I begyndelsen af maj læser Grundtvig i Nyeste Skilderie J. Krag Høsts rationalistiske redegørelse for, hvad der er den sande kristendom, og han giver sig nu til at udarbejde det apologetiske værk, det vil sige det forsvar for kristendommen, som kendes under navnet "Brevvexling mellem Nørrejylland og Christianshavn", og som er citeret ovenfor men Grundtvig afbryder affattelsen heraf for i stedet at blive digter og lade billedsproget komme til orde i Nyaars-Morgen - det, der afspejler sig i Syvende Sang. Til brevvekslingen lægger sig det i Theologisk Maanedsskrift 1825 udgivne, men i 1824 forfattede skrift "Om Natur og Aabenbaring", hvori Grundtvig taler om "menneskehjertet og åbenbaringen" (ibid., 8). Thaning vier imidlertid de 12 afhandlinger om den sande kristendom og om kristendommens sandhed sin hovedinteresse, idet han afdækker, hvorledes de tre første stykker er skrevet før opdagelsen, de sidste efter. Thaning rekonstruerer, hvorledes Grundtvig i 1825 i en række udkast til de sidste afhandlinger arbejder sig frem til den "erkendelse", at

den kristne tro blev først mundtligt forkyndt i verden; og før der var skrevet "en Tøddel" af det Ny Testamente, kaldte man de troende i Antiochia kristne, så kristendom er ikke oprindelig navnet på det $\mathrm{Ny}$ Testamentes tusinde Læsere, men på dem, "der bekiendte Tro paa Jesum Christum, den Korsfæstede igien Opstandne, Guds eenbaarne Søn og Verdens Frelser" (ibid., 12).

For Thaning er denne opdagelse første trin i den "totrinsraket" (ibid., 13), som den mageløse opdagelse udgør:

Det første trin var opdagelsen af, at der var kristne før bogen, hvad Grundtvig som god lutheraner ikke før har tænkt på. Kirken var altså til, før der var skrevet en tøddel af det Ny Testamente (ibid., 13).

Thaning gør videre rede for, hvorledes dette nybrud adskiller sig fra, hvad der skete i 1824, da Grundtvig afbrød sin apologetik for at blive 
digter. Thaning fremfører, at 1824 for Grundtvig var præget af en romantisk inspireret betoning af digterrolle og billedsprog:

I 1824 havde han følelsen af at have ånden i sig. Nu vil han henvise til ånden i kirken, til sin moders ord. Som noget nyt i denne sammenhæng vil han desuden forsvare hjertets rettigheder og knytter dermed til ved ... "Om Natur og Aabenbaring" (ibid., 16).

Thaning gør nu videre rede for, hvorledes Grundtvig har arbejdet videre hen imod sin opdagelse gennem affattelsen af en dialog $\mathrm{i}$ Holberg-stil, at han på et tidspunkt bliver sjusket i skriften - måske falder i søvn, og drømmer den berømte drøm, hvor han spiller skak med Djævelen og hvor en engel eller Kristus selv giver ham det afgørende, vindende skaktræk - den apostoliske trosbekendelse. Thaning identificerer på det grundlag fasc. 106 som det første udtryk for "den kirkelige Anskuelse", og slutter så afhandlingen med at beklage, at Grundtvig nåede så langt. For Thaning er det første "trin" i "totrinsraketten", dét at der var kirke, før der var skrift, det afgørende. Selve det, at Grundtvig "måtte (...) revidere sit apologetiske stade og finde sig selv som den lyttende i forholdet til kirken" (ibid., 28), er det afgørende, og han fastholder, at "Ordet af vor Herres egen Mund" (ibid.,) "kunne (...) have været forkyndt uden den opdagelse, som blev foræret Grundtvig under hans forbitrede kamp med kætterne" (ibid.,), og for Thaning er det afgørende, at Grundtvig først i 1832 endeligt frigøres fra den i virkeligheden højkirkelige dødvægt, som læren om Den apostoliske Trosbekendelse ifølge ham udgør. Thaning bestræber sig således på at forstå Grundtvig bedre, end denne forstod sig selv den tendens, der er i Grundtvigs forfatterskab til at bruge Den Apostoliske Trosbekendelse som "et våben i kirkekampen, et kætterjagtmiddel" (ibid.,) har Thaning det ikke godt med. I det stykke ligner han Chr. Thodberg.

Chr. Thodberg har i sin forskning ligesom A. Pontoppidan Thyssen peget på kontinuiteten i Grundtvigs forfatterskab, den fortsatte udvikling af motiver og således underbetonet det begreb om "selvopgør", der betyder så meget i Thanings optik. Thodberg ønsker som Thaning påvirket af "Guds ord"-teologien - at underbetone den kirkelige anskuelses tendens til at gøre trosbekendelsen til et redskab til at måle, om den rette kristentro er til stede, for i stedet at fastholde, at trosbekendelsen for Grundtvig står i forbindelse med hans fokusering på Guds ords skabende og tilsigende karakter. Thodberg har således peget på, at spørgsmålet om samtidigheden er afgørende for Grundtvigs gudstjenstlige teologi:

hvordan blev de bibelske beretninger og dermed frelsen selv samtidig med ham? Hvordan kunne han få at høre og vide, at Jesu ord gjaldt 
ham? Man kan roligt sige, at det var hans livs hovedproblem og drivkraften i hele hans teologiske tænkning" (Thodberg 1985, 128).

For Thodberg er Kristus nærværende i sit tilsigende ord, og han fremhæver, at Grundtvig derfor fokuserer på "evangeliets tiltaleord i imperativets form" (Pedersen 2003, 158). Dette står i forbindelse med, at Thodberg $\mathrm{i}$ sine analyser af den tætte sammenhæng mellem Grundtvigs prædikener og salmer er nået frem til, at Grundtvig $\mathrm{i}$ 1820 'erne op til den mageløse opdagelse arbejder med en række "prosapoetiske prædikener", præget af "prosapoetiske udbrud" (Thodberg 1997, 249), der danner forstadiet til egentlig poesi, korte, sideordnede sætninger, der udgør et led i udviklingen frem til den mageløse opdagelse, hvorefter man ifølge Thodberg "lidt overfladisk" kan "sige, at poesien i forkyndelsen måtte give plads for den dogmatik, der fra nu af blev den grundtvigske bevægelses bannermærke" (ibid., 269-270), men at prosapoesien derfor ikke forsvinder helt. For Thodberg udgør Grundtvigs prædikenvirksomhed i tiden omkring Sang-Vaerkets tilblivelse et højdepunkt, her bliver denne kerygmateologi til præsentisk eskatologi, altså en understregning af frelsen som nutid, godt hjulpet på vej af Grundtvigs oversættelser af de græske salmer:

Den græske kirkes stærke tale om gudstjenestens samtidighed med den himmelske gudstjenestes gang udtrykt i det gentagne i dag bekræftede Grundtvigs vision om den sammensmeltning mellem det menneskelige og det guddommelige, som den fornyede lovsang som svar på og gentagelse af Guds løfter skulle etablere (Thodberg 1989-1993, 30).

Og medens Thodberg som Thaning har reservationer i forbindelse med dogmatiseringen af Den Apostoliske Trosbekendelse, er han begejstret for Grundtvigs dåbsteologi som et udtryk for Guds tilsigende ord:

Bibelens beretninger tolkes og udlægges af ritualordene, der gør Jesu kraftige gerninger nærværende i Menigheden. Hvis Bibelen ikke forkyndes på den måde, er det en død tekst: "Den blotte Beskrivelse og Læsning" af Bibelen nytter nemlig ikke; Kristus er den samme til evig tid og gør stadigvæk i gudstjenesten de samme kraftige gerninger, som han gjorde i begyndelsen (Thodberg 2000, 123).

Det er Thodberg magtpåliggende at fremhæve, at Grundtvig i kraft af denne side af den kirkelige anskuelse dybest set giver sig selv en fri, kreativ tilgang til Bibelens skriftsteder - Thodbergs nøgleeksempel er Grundtvigs begejstring for beretningen om Enkens fra Nains søn, hvor Jesu bydeord får nutidig karakter. Til den eksegetiske forsker Hejne Simonsens erkendelse af, at Grundtvig i sit konkrete, tekstkritiske arbejde når frem til "yderst konservative" "resultater" (Simonsen 
1983, 23) lægger sig altså Thodbergs fremhævelse af Grundtvigs frie, poetisk stærke og "Guds Ord”-teologisk funderede brug af Bibelens skriftsteder.

Thaning og Thodberg kan for så vidt mødes i en fælles understregning af Grundtvigs "Guds ord"-teologi, det vil sige i en betoning af kristendommens sandhed som eksistentiel tiltale af menneskehjertet, om end Thaning - som det fremgik ovenfor - er langt mindre begejstret for Grundtvigs prosapoesi end Thodberg. Thodberg vælger i sin tolkning at se bort fra det forhold, at Grundtvig ikke blot lod sin understregning af "Guds Ord til os" ved "Badet og Bordet" fremhæve Gudsordets tilsigende karakter, men også bruger Apostolikum som et teologisk alenmål til at måle kristnes rettroenhed. Thaning arbejder med problemet, men lider ligesom Thodberg ikke dette træk ved Grundtvig. Det er da også klart, at begge aspekter - det tilsigende og det teologisk-målende - er at finde i Grundtvigs kirkelige anskuelse.

Som eksempel på "opdagelsen" vælges her da Grundtvigs fremstilling heraf i den berømte prædiken til 9. Søndag efter Trinitatis $1825-$ forud for Kirkens Gienmale, hans stridsskrift mod H. N. Clausen, hvor Grundtvig gør det klart, at

hvad der end staaer i Bibelen, saa er det jo lige vist og lige unægtelig, at den Troes-Bekiendelse, de Christne til alle Tider, $\mathrm{i}$ alle Menigheder har aflagt, den og ingen anden er de Christnes Troesbekiendelse, ..." (Thaning 1982, 14).

Blandt de utallige eksempler, man kunne fremdrage på Grundtvigs egen "Guds Ord"-teologiske tolkning af anskuelsen, vælges her at fremdrage de sidste dele af de 12 afhandlinger om kristendommens sandhed og den sande kristendom, i Grundtvigs understregning af "det levende Ord" "Ordet", der er mennesket "nær" i dets "Mund" og "Hjerte" (US IV, 686).

Endelig er det vigtigt at fremdrage tre andre tekster, der belyser konsekvenser af den kirkelige anskuelse.

For det første Grundtvigs tendens til at bruge den som alenmål til at måle kristnes rettroenhed med - her inddrages det berømte sidste brev til vennen B. S. Ingemann, hvori Grundtvig fremfører, at "Den Apostoliske Trosbekendelse er Den uforanderlige og urokkelige christne Grundlov" (Grundtvig 1882, 327), og at man, hvis man bryder denne, udelukker sig af den kristne menigheds fællesskab.

For det andet det forhold, at Grundtvigs opdagelse af, at ordet er før skriften, fører ham til at forkaste læren om verbalinspiration. Grundtvig gør i sin afhandling om nytestamentlig tekstkritik i almindelighed og i Alcalateksten i særdeleshed klart, at "Kritiken", det vil sige Bibelkritikken, har "gjort os det umueligt at grunde Kirken 
paa og udlede Troen af Bibelen" men at "Apostlernes Skrifter forudscette (...) Troen hos deres Loesere" (Grundtvig 1837, 827), at det levende ord altså går forud for skriften, et forhold, der gør, at Grundtvig kan se roligt på, at bibelkritikken også har "gjort det umueligt at forsvare de Lutherske Theologers Larescetning om Bibelens Indblæsning (Inspiration) fra Begyndelsen til Enden" $(\text { ibid. })^{17}$. Grundtvig accepterer altså bibelkritik, om end han, som påpeget ovenfor af Hejne Simonsen, er temmelig konservativ, når det gælder dens konkrete resultater samtidig med, at han, som Chr. Thodberg viser, kan forholde sig kreativt til bibelsteder ved at aktualisere dem poetisk i sin prædiken.

Dette fremgår også af den tredje og sidste tekst, der inddrages $i$ dette afsnit, Grundtvigs ord i en samtale i 1863, hvor han med hånden på Bibelen skal have sagt, at han "tror alt, hvad der staar skrevet $i$ denne Bog" (Holm, GE, 237), om end han ikke forstår alt - forståelsen er i bevægelse, udvikler sig frem til tidens ende. Grundtvig fæster altså overvejende lid til Bibelens ord.

VIII. Redegørelse for de personlige traek $i$ Grundtvigs selvopgør og teologihistorisk indplacering og vurdering af Grundtvigs udvikling i 1821-1823-1825

Det er næsten overflødigt at påpege strukturlighederne mellem Grundtvigs omvendelse i 1810 og nybruddet i 1821 og 1823 frem til 1825: Grundtvig arbejder på en national opgave: de store oversættelser, der skal give det danske folk dets folkelighed tilbage - og går altså på sin vis ind i reformator-rollen, samtidig med, at han jo netop i den "historiske" periode arbejder folkeligt og kristeligt i ét; gennem oplevelsen af død lider Grundtvigs reformatoriske anstrengelser et knæk, gennem fokuseringen på Helligåndens og dermed på det ydre ords gerning modificeres reformatorrollen - alt det, der kulminerer med den mageløse opdagelse i 1825 .

Rent teologisk medfører den kirkelige anskuelse virkelig frihed $\mathrm{i}$ forhold til Bibelen: Grundtvig grunder ikke længere kristendommen på Bogen, men på det levende ord, han accepterer elementer af bibelkritik og han tager eksplicit afstand fra læren om verbalinspiration. Samtidig er der stærke vidnesbyrd om, at Grundtvig opfatter Den Apostoliske Trosbekendelse som bogstavelig sandhed og tilkender bekendelsens sætninger en status, der ligner den, fundamentalister giver Bibelen.

Hvis man igen inddrager den teologiske fundamentalisme-definition, afviser Grundtvig verbalinspirationen - men hans fokusering på trosbekendelsen kan på en vis måde siges at ligne fundamentalisternes 
5-punkts-lære - i hvert fald, hvis man vælger at se bort fra de "Guds Ord"-teologiske træk i Grundtvigs teologi og fokusere på de apologetiske træk heri, altså hans arbejde med at fremhæve trosbekendelsen som bærer af den sande kristendom og derfor som et måleredskab, hvormed man kan måle menneskers rettroenhed. Men hvad så med den teologiske fundamentalisme-definitions fremhævelse af kampen mod en (natur)videnskabelig verdensforklaring og hvad med den profanhistoriske fundamentalisme-definitions fremhævelse af, at fundamentalister forsøger at skabe religiøs uniformitet i samfundet, altså reformere en sekulær stat? For at besvare disse spørgsmål er det vigtigt igen at inddrage Ole Vinds karakteristik af Grundtvig som fundamentalist.

\section{Ole Vinds fundamentalisme-begreb undersøgt $i$ sammen-} hoeng med Grundtvigs skelnen mellem kristne og naturalister af ånd samt Haandbog i Verdens-Historien

Ole Vind anklager som sagt Grundtvig for fundamentalisme, dels fordi Grundtvig ifølge Vind mener, at de bibelske forfattere var "direkte inspireret" af Gud, dels fordi han betragter tekststykker som skabelsesberetningen og Babelsmyten som bogstaveligt sande beretninger om faktuel, stedfunden historie. $\mathrm{Nu}$ er det jo, som vi så i forbindelse med Alcala-teksten, for Grundtvig langtfra altid tilfældet, at de bibelske forfattere skriver på inspiration. Og Vind gør ikke nærmere rede for, hvad der ligger i hans "direkte". Men hvad med Grundtvigs opfattelse af skabelsesberetningen og Babelsmyten? Ja, Ole Vind har ret, når han hævder, at Grundtvig betragter disse to tekster som en form for historieskrivning - samtidig med, at nogle af Grundtvigs teorier om geologi ifølge Vind deltes af hans samtidige, der ikke som Grundtvig kan komme under Vinds anklage for fundamentalisme. Men håndbogen er blevet til på baggrund af Grundtvigs skelnen mellem - og invitation til samarbejde mellem - kristne og naturalister af ånd $\mathrm{i}$ Nordens Mythologi fra 1832. Og hvis man går Vinds kilde, Haandbog $i$ Verdens-Historien efter, viser det sig, at Grundtvig begge steder ved siden af sin egen opfattelse stiller naturalisternes tolkning af de to beretninger som myter. Grundtvig medgiver i forbindelse med skabelsesberetningen, at denne kan opfattes som en myte:

Hvorvidt nu derved skal forstaaes Andet end det med Guddoms-Aande oplivede Menneskes Grund-Anskuelse af Skabningen og Skaberen, derom kan Man tvistes, men guddommelig er alle Dage denne Forestilling om Verdens Ophav, thi den er, som ingen Anden, baade 
Guddommen værdig og passende til Menneske-Aandens høieste Flugt og til Hjertets dybeste Rørelser, (US VI 45).

Og om Babelsmyten læser man, at Grundtvig her "indskyder" sig "under Skole-Raadet" og derfor ikke opfatter Babelstårnet som en "Troes-Artikel til Salighed" (US VI 57), men "som et reelt videnskabeligt Spørgsmaal, hvad Priis vi skal sætte paa Efterretningerne om Babels-Taarnet" (ibid.)

Grundtvig lader beretningen høre ind under skolens område, og dermed ind under, hvad der er åbne, det vil sige videnskabelige spørgsmål. $\mathrm{Og}$ selv om han regner med, at tiden efterhånden vil vise, han har ret $\mathrm{i}$ at opfatte beretningen som bogstavelig sand historieskrivning, er han parat til at lade det være uafgjort, indtil beviset foreligger.

Regin Prenter gør i sit oppositionsindlæg ved Kaj Thanings forsvar rede for, at Thanings forsøg på at stille 1832 op som et modstykke til 1825 , det vil sige som en befrielse i Grundtvigs forfatterskab fra en højkirkelig dødvægt, ikke holder stik. Der er en klar forbindelse mellem de to begivenheder: netop, fordi Grundtvig i 1825 er nået frem til et klart kirke- og kristendomsbegreb, bliver han "fri" til at samarbejde med naturalisterne af ånd. Den klare skelnen mellem kristendommen som kristologisk begrundet forløsningstro og naturalisternes opfattelse af Jesus som forbillede for menneskets selvforløsning, som er så stærkt fremtrædende i Nordens Mythologi 1832, er kun mulig i kraft af 1825. Derfor går der en lige linje fra Grundtvigs mageløse opdagelse til 1832's skelnen og deraf følgende samarbejde (Prenter 1964, 193).

\section{Afslutning: Var Grundtvig fundamentalist?}

Som det fremgik både af den teologiske og den profanhistoriske fundamentalisme-definition, er fundamentalister fjendtligt indstillede over for naturvidenskabelige (verdens)forklaringer - uanset, om de ønsker at holde staten og det offentlige skolevæsen fri for sådanne eller blot ønsker dem væk fra deres egne skoler, der så vil blive drevet som en form for stat i staten. Og som det fremgik, er fundamentalismen her blevet til som reaktion på naturvidenskabens uhyre indflydelse efter 1850. Endelig reagerer fundamentalisterne på en omfattende urbanisering og industrialisering, et brud på den traditionelle levevis. Grundtvig passer ikke ind i noget af dette. Det afgørende træk, der skiller Grundtvig fra fundamentalisme, er for så vidt ikke hans brud med bibelkristendommen i 1823-24-25 eller hans dermed forbundne afvisning af verbalinspirationen, men snarere hans åbning i 
forhold til naturalisterne af ånd, og dermed denne åbnings teologiskidemæssige begrundelse $i$ to centrale begreber: skoletanken, det vil sige sondringen mellem kirke og skole og frihedstænkningen - skolebegrebet og frihedsbegrebet er uløseligt forbundne. Det bør være indlysende for enhver, at Grundtvigs tematisering af friheden står i forbindelse med hans modernitetsbevidsthed - også, selv om han livet igennem er en ( $\mathrm{i}$ et vist omfang medtænkende) kritiker af Kants autonomi-begreb. Det moderne positive begreb om meningsmæssig pluralisme, som er forbundet med frihedstanker, er markant udtrykt i Den danske Stats-Kirke upartisk betragtet, hvor han lader en videnskabelig "Tvist" være et afgørende særkende for "Nyaars-Tiden" (US IV, 72, 89 ff.), ja, selve forudsætningen for, at denne kan holdes spændstig og fuldføre sin opgave: forklaringen af menneskelivet.

Forkortelser

$B G$ I-II: Georg Christensen og Stener Grundtvig (udg.) (1924), Breve fra og til Grundtvig, 1807-72, bind 1-2, København.

GP I-XII: Chr. Thodberg (udg.) (1983-86), Grundtvigs Proedikener 1823-24, bind 1-12, København.

GE: Steen Johansen og Henning Høirup (red.) (1948), Grundtvigs Erindringer og Erindringer om Grundtvig, 1 bind, København.

Nordens Mythologi: N. F. S. Grundtvig (1832), Nordens Mythologi eller Sindbilled-Sprog - Historisk-Poetisk udviklet og oplyst af N. F. S. Grundtvig, København.

Nyaars-Morgen: N. F. S. Grundtvig (1824), Nyaars-Morgen. Et Rim, København.

US I-X: Holger Begtrup (udg.) (1904-09), Nik. Fred. Sev. Grundtvigs Udvalgte Skrifter, bind 1-10, København.

VK 1812 og VK 1817: N. F. S. Grundtvig (1812-17), Kort Begreb af Verdens Krønike i Sammenhong, København

\section{Litteraturliste}

\section{Værker af Grundtvig}

Begtrup, Holger (udg.) (1904-09), Nik. Fred. Sev. Grundtvigs Udvalgte Skrifter, bind 1-10, København.

Bugge, K. E. et al. (1983), N. F. S. Grundtvig: Statsmoessig Oplysning, København.

Christensen, Georg og Stener Grundtvig (udg.) (1924), Breve'fra og til Grundtvig, 1807-72, bind 1-2, København.

Grundtvig, N. F. S. (1811), "Brev til W. Østrup" i BG I, 38-40. 
- (1812), "Brev til J. P. Mynster" i $B G$, I, 98-100.

- (1812), Kort Begreb af Verdens Krønike i Sammenhoeng, US II, $165-422$.

- (1814), Erklæring i Nyeste Skilderie af Kiøbenhavn, II. Aarg. $1814,1140-42$.

- (1817), Udsigt over Verdens-Krøniken, fornemmelig $i$ det Lutherske Tidsrum, Kjøbenhavn.

- (1823-1824), "Brevveksling mellem Nørrejylland og Christianshavn (H. Begtrups titel)" i $G E, 58-69$.

— (1824), Nyaars-Morgen. Et Rim, København.

— (1825), "Om Natur og Aabenbaring" (1824), Theologisk Maanedsskrift.

- (1826-1827), “Om den sande Christendom og om Christendommens Sandhed" i US IV, 442-519.

- (1832), "Nordens Mythologi eller Sindbilled-Sprog historiskpoetisk udviklet og oplyst" i US V, 376-768.

— (1837), "Om det Ny Testamente i Grundsproget eller Om AlcalaTexten og Bibel-Kritiken" i Nordisk Kirketidende, 1837, Nr. 5255, 817-831, 833-848, 849-864, 885-898.

- (1833-1843), "Haandbog i Verdens-Historien. Efter de bedste Kilder. Et Forsøg. Oldtiden" i US VI, 5-531.

— (1834), "Den danske Statskirke upartisk betragtet" i US VIII, 5298.

— (1840), “Jødernes Valgbarhed til det Danske Folkeraad”, Brage og Idun, Hefte 1, 319-328.

— (1855-61), "Den christelige Børnelærdom" i US IX, 329-595.

— (1862-1863) "Kirke-Speil" i $G E, 86-112$.

Grundtvig, Svend (udg.) (1882), Grundtvig og Ingemann. Brevvexling 1821-1859, København.

Johansen, Steen og Henning Høirup (red.) (1948), Grundtvigs erindringer og erindringer om Grundtvig, 1 bind, København.

Thodberg, Chr. (udg.) (1983-86), Grundtvigs Prcedikener 1823-24, bind 1-12, København.

\section{Værker af andre}

Aarnes, Sigurd Aa. (1961), Historieskrivning og livssyn hos Grundtvig. En undersøkelse av toverdensmotivet $i$ verdenskrønikene, Oslo.

Auken, Sune (2005), Sagas spejl, Mytologi, historie og kristendom hos N. F. S. Grundtvig, København.

Begtrup, Holger (1901), Grundtvigs kirkelige Syn, København. 
Begtrup, Holger (1909) Indledning, Udvalgte Værker af N. F. S. Grundtvig, IX, 49.

Catholic Answers:

$<\mathrm{http}$ ://www.catholic.com.library/Fundamentalism.asp $>$.

Christensen, Bent (1987), Fra drøm til program: Menneskelivet og dets verdens plads og betydning i N.F.S. Grundtvigs kristendomsforståelse fra Dagningen i 1824 over Opdagelsen $i 1825$ til Indledningen i 1832, København.

Christensen, Torben og Göransson, Sven (1976), Kyrkohistoria, I-III, III, Lund.

Eriksson, Gunnar og Svensson, Lena (1986), Vetenskapen $i$ underlandet, två studier i populärvetenskap, Stockholm.

Eisenberg, Christian (1993), Ein unbeachteter Artikel N. F. S. Grundtvigs aus dem Jahre 1837: Om det Ny Testamente $i$ Grundsproget eller om Alcala-Texten og Bibelkritiken; GrundtvigStudier 1993, bind 44, København, 214-236.

Garff, Joakim (2002), "Hvad har dog ikke denne Pen formaaet...'. Om det æstetiske hos Kierkegaard" i Henrik Wigh-Poulsen et al. (red.), Grundtvig-Kierkegaard, en samtale på høje tid, København, 187-205.

Grøndahl, Malene (2001), "Religiøs fundamentalisme", Information den 13. december 2001:

$<$ http://www.faktalink.dk/publish.php?linknavn=refu>.

Helweg, Hjalmar (1932), N.F.S. Grundtvigs Sindssygdom, København, Holm, Jakob (1909), Dansk Kirketidende, sp. 744, her fra GE, 237238.

Islaminfo.dk, "Bogens folk": $<\mathrm{http}: / /$ www.islamstudie.dk/etik_leveregler.venskab.htm>.

Karlsmose, Marianne (2002), "Plads til kritik af Darwin": $<\mathrm{http} / /$ www.religion.dk/tema/tema:fid=100003720:aid=30990>.

Kofoed, Niels (1954), Grundtvig som selvbiograf, København.

Koselleck, Reinhard (1979), "Neuzeit: Zur Semantik moderner Bewegungsbegriffe" in Vergangene Zukunft, Frankfurt am Main, 300-348.

Korsgaard, Ove (2004), Kampen om folket: Et dannelsesperspektiv på dansk historie gennem 500 år, København.

Kristeligt Dagblad (2002), "Ghandis vision truet”, 5/3 2002.

Kronberg, Robert (2003), Hvad er fundamentalisme: $<$ http://www.religion.dk/surfguide/artikel:aid=50465>.

Lindholm, Poul og Ågård Højskoles elevforening (udg.)(1922), Brücker, V. "Kristendom og Skriftteologi" (1886) i Brücker, V., et

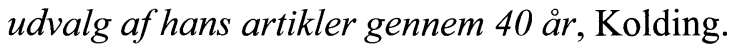


Lundgreen-Nielsen, Flemming (1980), Det handlende Ord: N. F S. Grundtvigs digtning, litteraturkritik og poetik 1798-1819, bind 12, København.

Michelsen, William (1956), Grundtvig 1820, "Lidet om Jesu Christi Aabenbaring", Grundtvig-Studier 1956, bind 9, 64-74.

Mosbech, Holger (1934), Fortolkning af Johannes Aabenbaring $i$ Fortid og Nutid, København.

Neiiendam, M. (1922), Christian Bastholm. Studier over Oplysningens Teologi og Kirke, København.

Neturei Karta: <http://www.nkusa.org>.

Nielsen, Mikkel Crone (2002), "At tale med de døde..."Om sækularisering og hermeneutik i Kaj Thanings forfatterskab" Grundtvig-Studier 2002, bind 53,København, 121-141.

Nørager, Troels (1989), System og livsverden: Habermas' konstruktion af det moderne, København.

PBS American Expierience: <http://www.pbs.org/wgbh/amex/carter>

("timeline", "people and events").

PBS Home Frontline The Jesus Factor:

$<$ http://www.pbs.org/wgbh/pages/frontline/shows/jesus/>.

Pedersen, Kim Arne (2003), Den teologiske Grundtvigforskning siden

Anden Verdenskrig i H. Sanders og O. Vind (red.), Grundtvig:

Nycklen till det danska?, København, 150-179.

Princeton Theological Seminary: <http://www.ptsem.edu/About $>$.

Prenter, Regin (1964), "Kaj Thanings Grundtvig-bog”, Dansk

Theologisk Tidsskrift, 1964: 4, 193-210.

Rønne, Finn Aa. og Andersen, Leif (2002), Da kristentro og

fundamentalisme gik hver til sit:

$<\mathrm{http}$ ://www.religion.dk/tema/tema:fid=100002300:aid=19859>.

Scharling, Henrik, (1891), Grundtvig eller Luther. Et Blik paa Nutidens danske Kirkeforhold, København.

Schjørring, J. H. (1990), Grundtvigs billedsprog - og den kirkelige anskuelse, København.

Schmidt, Rudolf, (1883) Grundtvig og den tyske ortodoksi. En historisk Sammenstilling, København.

Simonsen, H. (1983), "Grundtvig som ekseget” i N. F. S. Grundtvig, theolog og kirkelærer. Prædikener og foredrag fra 200-året, Christiansfeld, 20-32.

Thaning, K. (1953), "Grundtvigs møde med Irenæus - hans vej til 'Dagningen' og 'de levendes Land'”, Grundtvig-Studier 1953, Bind 6, 7-68.

(1963), Menneske først - Grundtvigs opgør med sig selv, bind 1-3, København. 
(1981), "Den 'mageløse opdagelses' tilblivelse", GrundtvigStudier 1981, København, Bind 33, 7-29.

— (1982), "Grundtvigs Prædiken den 31. Juli 1825, Niende Søndag efter Trinitatis (Aften-Sang), Grundtvig-Studier 1982, 7-16.

— (1987), "Grundtvigs prædiken den 31. juli 1825", GrundtvigStudier 1987, bind 33, København, 11-55.

The Free Dictionary: <http://www.thefreedictionary.com/chasidism>.

Thodberg, Christian (1985), "Grundtvigs Bibelsyn" i Sigfred Pedersen (red.), Skriftsyn og metode, Århus, 126-142.

— (1986), Grundtvigs skovoplevelse i 1811 og prodikenerne over Peters fiskedrcet i tiden, der fulgte, København.

- (1989-1993), "Grundtvigs græske vækkelse og Sangværket", Dansk Kirkesangs Arsskrift 1989-1993, 10-33.

- (1997), "At tale en sang: Grundtvigs poetiske raptus på prædikestolen" i Poul Lindegård Hjort, Erik Dal og David Favrholdt (red.), Fra Egtvedpigen til folketinget, Et Festskrift til Hendes Majestoet Dronning Margrethe II ved regeringsjubiloet 1997, København, 245-271.

- (2000), "Den liturgiske eksegese og Grundtvig", GrundtvigStudier 2000, bind 51, København, 118-125.

Thyssen, A. Pontoppidan (1967), Grundtvig og Spener - isaer til belysning af den 'pietistiske' Grundtvig, Grundtvig Studier 1967, bind 19, 9-50.

— (1983), "Grundtvigs tanker om kirke og folk 1825-1847" i A. Pontoppidan Thyssen og Christian Thodberg, (red.), Grundtvig og grundtvigianismen i nyt lys, Århus.

Thyssen, Peter (1997), "Grundtvig og Guds Ord-teologien" i Peter Thyssen og Anders Moe Rasmussen (red.), Teologi og modernitet, Århus, 66-79.

Vind, Ole (1998), Grundtvigs historiefilosofi, København.

— (2004), "Tilbage til den åndelige højskole", Kristeligt Dagblad 6.1.2004.

Vogel, Ulrich (1993), Bankede på ved Paradis. Grundtvigs kriseoplevelser, Frederiksberg.

Wikipedia, "Amish": <http://en.wikipedia.org/wiki/Amish>.

—, "Wahhabism": <http://en.wikipedia.org/wiki/Wahhabism>.

Østergård, Uffe (2001), "Fundamentalisme er moderne", Information

4. august 2001:

$<$ http://www.diis.dk/graphics/CVer/Personlige_CVer/Holocaust_a nd_Genocide/Publikationer/uffe_fundamentalisme.pdf $>$. 
Noter

Nærværende arbejde er blevet til i forbindelse med GrundtvigAkademiets kursus "Kristen fundamentalisme" i januar 2004. Det støtter sig i vidt omfang til foreliggende forskning, idet sigtet først og fremmest har været at skrive en oversigtsartikel og deri at holde Grundtvig sammen med fundamentalismen i perspektiv af primære og sekundære tekster til belysning af Grundtvigs bibelsyn.

Thaning (1963). - Se hertil Nielsen (2002, 161 ff.) og Pedersen (2003, $121 \mathrm{ff}$.).

Se eksempelvis “Ghandis vision truet”, Kristeligt Dagblad, 13. maj 2002. Fundamentalisme bruges også i en anelse mere præcis betydning som dét at tænke og handle ud fra nogle forudsætninger, der ikke står til diskussion. Anklagen for fundamentalisme i denne betydning rammer imidlertid ganske mange forhold i tilværelsen - eksempelvis bliver det vanskeligt for tilhængere af religiøse læresætninger at hævde disse som teologisk udgangspunkt - også, hvis tilhængerne medgiver, at disse kan fortolkes forskelligt.

5 Vinds karakteristik af Grundtvig som fundamentalist har sat sine spor. Her kan eksempelvis henvises til Ove Korsgaard, der i sin disputats arbejder med en form for sprog-fundamentalisme hos Grundtvig, en tolkning af Grundtvig som gørende folkesprogene til absolutte og uoverskridelige fundamenter for menneskeliv og historie. Udover, at begrebet fundamentalisme her føres meget vidt, kan denne tolkning kritiseres (Korsgaard 2004, 284). I artiklen "Jødernes Valgbarhed til det Danske Folkeraad" har Grundtvig (1840) gjort rede for, hvorledes han forestiller sig det jødiske folks og det hebraiske sprogs skæbne i nutiden en tekst, der - med alvorlige følger for Vinds opfattelse af Grundtvig som etnisk nationalist - ikke optræder på Vinds litteraturliste.

Se eksempelvis Scharling 1891 og Schmidt 1883.

7 Her knyttes til ved Reinhard Kosellecks analyser af tidsbegrebet og det moderne (Koselleck 1979, 314) i kombination med det modernitetsbegreb, som Jürgen Habermas gør sig til talsmand for, se nedennævnte inddragelse af Troels Nørager.

8 På den kristne højrefløj er man heller ikke begejstret for betegnelsen fundamentalisme, se Rønne og Andersen 2002.

9 For en redegørelse for Grundtvigs kriser, se Ulrich Vogel.

10 Se hertil bl.a Fl. Lundgreen-Nielsen, Det handlende Ord, Kbh. 1980, I-II, I, 278.

11 Til teologisk rationalisme, se eksempelvis Neiiendam 1922, $47 \mathrm{ff}$., $307 \mathrm{ff}$.

12 Til syvstjernemotivet, se blandt andet Auken 2005, $554 \mathrm{ff}$.

13 Se eksempelvis Grundtvigs første verdenskrønike, US II, $301 \mathrm{ff}$. 
Der kan være grund til at gøre opmærksom på A. Pontoppidan Thyssens afhandling Grundtvig og Spener. Især til belysning af den "pietistiske" Grundtvig, Grundtvig-Studier 1967, hvori Thyssen foruden det fælles motiv kirkens forfald og oprejsning peger på, at der både i pietismen og hos Grundtvig tales om "det personlige forhold til kristendommen" (ibid., 43), men at Grundtvig betoner det "objektive" (ibid., 46) i kristendommen stærkere.

Grundtvigs modernitetsbegreb står i forbindelse med hans forhold til oplysningstiden og begrebet oplysning. I det først i vore dage trykte skrift Statsmaessig Oplysning fra 1834 møder man i Grundtvigs nuancerede forhold til oplysningstiden - en position, der ikke er reserveret til det i Grundtvigs tid utrykte skrift, men også kan genfindes i Haandbog $i$ Verdens-Historien fra $1833 \mathrm{og}$ frem. I haandbogen arbejder Grundtvig med tanken om, at mennesket står i tre grundforhold (Grundtvig, "Haandbog i Verdens-Historien" i US VI, 26-27), til Gud, medmennesket og sig selv. Det grundforhold, der her tages under behandling, er det, der for Grundtvig kommer til sidst: menneskets selvforhold, dets refleksion, det vil sige det, at mennesket refleksivt bøjer sig tilbage mod sig selv i sin bevidsthed. For Grundtvig er refleksionen et uomgængeligt grundvilkår for den klassiske modernitet. Samtidig er refleksionen forbundet med det forhold, at mennesket nu er nået til sin skolealder, til den eftertankens tid, som er knyttet sammen med bevidsthedens tænkearbejde. Her er det, som det fremgår af Nordens Mythologi fra 1832, afgørende, at den oplysning, som kommer ud af skoletiden, skal være folkelig og ikke elitær, det vil sige sigte mod en fælles midte i dannelsen: "Ja, Folkelig Vidskab eller Folke-Dannelse og Folke-Oplysning i rigtig, aandelig Forstand, det er det andet nødvendige Kampe-Skridt, der maa giøres uopholdelig, hvor Opløsningen skal forebygges, Folke-Livet reddes, og Videnskabelighed trives" (Grundtvig, Nordens Mythologi 1832, US V, 406). "Opløsningen" er Grundtvigs brander, hans fordrejning af ordet "Oplysning". Dermed er ikke sagt, at Grundtvig er mod oplysning, og han fortæller, at han af oplysningstiden har lært at sætte pris på frihed og folkeoplysning. Og Grundtvig er meget bevidst om, at oplysningstiden er uomgængelig i menneskehedens historie, ligesom det er nødvendigt, at det enkelte menneske bliver voksent og myndigt, bliver i stand til at tænke skarpt og fastholde sin egen individuelle synsmåde. Grundtvig skriver om folkeslagenes myndiggørelse: "Nu lærer Verdens-Historien, at alle FolkeFærd, naar de komme til en vis Alder, komme i det Store til en lignende Oplysning, hvorved Enkelt-Manden, han være Ung eller Gammel, langt skarpere end før de Ældste, adskiller sig selv og Alt, hvad han kalder Sit, fra alt Andet baade i Himlen og paa Jorden og kræver, koste hvad koste vil, hvad han kalder sin Ret, som et frit Fornuft-Væsen" (Grundtvig, Statsmaessig Oplysning 1834, udg. v. K. E. Bugge og V. Nielsen, Kbh. 1983, 27). Bag Grundtvigs billede af menneskets krav på autonomi, selvlovgivning, som et frit væsen, et krav, der bliver til i oplysningstiden, 
ligger Immanuel Kants frihedsforståelse. For Kant er mennesket kun frit, idet det bøjer sig for den lov, det selv udkaster. Den fokusering på det enkelte menneske som autonomt fornuftsvæsen, der ligger bag Kant - og som genfindes i hans bestemmelse af oplysning som menneskets udgang af dets selvforskyldte umyndiggørelse - gør sammen med Hegel Kant til modernitetens tænker. Menneskets refleksive bøjen tilbage mod sig selv er modernitetens afgørende grundfigur, og Grundtvig er i høj grad bevidst om dette forhold. Det spændende er nu ikke her, at Grundtvig kan se farerne i den opsplitning, som følger i denne oplysningens alder - dét, at de enkelte individer, enkeltmændene, som Grundtvig siger - fastholder deres individuelle synsmåde og kræver at kunne styre eller lovgive sig selv. Det spændende er, at han på sin vis betragter denne udvikling som uundgåelig. Det er uundgåeligt, at det enkelte menneskes myndiggørelse såvel som de enkelte folkeslags myndiggørelse kommer. Derfor vil der nødvendigvis altid i denne moderne epoke optræde et væld af synspunkter, et væld af tolkninger af det ene og det andet. Det er som sagt ikke nødvendigvis et onde, men alligevel er det nødvendigt at fremholde noget foelles for alle mennesker, der kan danne modvægt mod den opløsning, som oplysningen nødvendigvis bliver til. Grundtvig sætter her en særlig folkelig oplysning ind som redningsmidlet, en oplysning, der “ . .. ved at udstrække sig til hele Menneske-Livet og opvise den dybe Sammenhæng mellem Enkelt-Mandens, Folkets og hele Slægtens Liv, udvikler en for alle selskabelige Forhold ønskelig Tankegang, ..." (ibid., 31). Grundtvig bruger her ordet selskabelig i dets gamle betydning som betegnelse for det, vi i dag ville kalde for samfundslivet eller samfundskulturen. Det spændende er, at Grundtvig lader tre livskredse høre med ind i den oplysning, der frem for opløsning eller splittelse siger sammenhæng: individets, folkets - og helt afgørende, hele menneskehedens liv. Til de tre livskredse svarer jo det enkelte menneske og dets selvforhold, menneskets forhold til medmennesket og - korresponderende med universaliteten, hele menneskeslægten, der for Grundtvig altid medfører gudsbegrebet - menneskets forhold til Gud. Men netop deri, at menneskets tre livskredse ifølge Grundtvig skal hænge sammen, ligger der et brud med modernitetens fokusering på subjektet og individet, der ligger en forståelse for, at mennesket kun bliver menneske i et forhold til den anden, til Gud og medmennesket.

16 Bent Christensen analyserer prædikenen til Alm. Bededag 1824, hvor Grundtvig prædiker om menneskehjertet som Guds bolig, men især Grundtvigs pinsemorgen-prædiken 1824, hvor Grundtvig fortolker pinsen som kærlighedens fest, som fuldendelsen i et vækstperspektiv, der svarer til barndom-ungdom-manddom. For Bent Christensen er hele denne prædiken et eksempel på "Guds nærvær i gudstjenesten, der fylder menigheden "her-og-nu" (Christensen 28-29).

17 Til en grundig gennemgang af Grundtvigs arbejde om Alcala-teksten, se Eisenberg 1993. 